\title{
Quantifying the impact of BOReal forest fires on Tropospheric oxidants over the Atlantic using Aircraft and Satellites (BORTAS) experiment: design, execution and science overview
}

P. I. Palmer ${ }^{1}$, M. Parrington ${ }^{1}$, J. D. Lee ${ }^{2}$ A. C. Lewis ${ }^{2}$ A. R. Rickard ${ }^{3, *}$, P. F. Bernath ${ }^{2, * *}$ T. J. Duck ${ }^{4}$, D. L. Waugh ${ }^{5}$ D. W. Tarasick ${ }^{6}$, S. Andrews ${ }^{7}$, E. Aruffo ${ }^{8,9}$, L. J. Bailey ${ }^{4}$, E. Barrett ${ }^{1}$, S. J.-B. Bauguitte ${ }^{10}$, K. R. Curry ${ }^{4}$, P. Di Carlo ${ }^{8,9}$, L. Chisholm ${ }^{5}$, L. Dan ${ }^{11}$, G. Forster ${ }^{12}$, J. E. Franklin ${ }^{4}$, M. D. Gibson ${ }^{13}$, D. Griffin ${ }^{11}$, D. Helmig ${ }^{14}$, J. R. Hopkins ${ }^{2}$, J. T. Hopper ${ }^{4}$, M. E. Jenkin ${ }^{15}$, D. Kindred ${ }^{16}$, J. Kliever ${ }^{11}$, M. Le Breton ${ }^{17}$, S. Matthiesen ${ }^{1}$, M. Maurice ${ }^{11}$, S. Moller ${ }^{2}$, D. P. Moore ${ }^{18}$, D. E. Oram ${ }^{12}$, S. J. O'Shea ${ }^{17}$, R. C. Owen ${ }^{19}$, C. M. L. S. Pagniello ${ }^{4}$, S. Pawson ${ }^{18}$, C. J. Percival ${ }^{17}$, J. R. Pierce ${ }^{4}$, S. Punjabi ${ }^{7}$, R. M. Purvis ${ }^{2}$, J. J. Remedios ${ }^{18}$, K. M. Rotermund $^{4}$, K. M. Sakamoto ${ }^{4}$, A. M. da Silva ${ }^{20}$, K. B. Strawbridge ${ }^{6}$, K. Strong ${ }^{11}$, J. Taylor ${ }^{17}$, R. Trigwell ${ }^{1}$, K. A. Tereszchuk ${ }^{7}$, K. A. Walker $^{11}$, D. Weaver ${ }^{11}$, C. Whaley ${ }^{11}$, and J. C. Young ${ }^{3}$

${ }^{1}$ School of GeoSciences, University of Edinburgh, Edinburgh, UK

${ }^{2}$ National Centre for Atmospheric Science (NCAS), Department of Chemistry, University of York, York, UK

${ }^{3}$ National Centre for Atmospheric Science (NCAS), School of Chemistry, University of Leeds, Leeds, UK

${ }^{4}$ Department of Physics and Atmospheric Science, Dalhousie University, Halifax, Nova Scotia, Canada

${ }^{5}$ Meteorological Service of Canada, Dartmouth, Nova Scotia, Canada

${ }^{6}$ Environment Canada, Toronto, Ontario, Canada

${ }^{7}$ Department of Chemistry, University of York, York, UK

${ }^{8}$ Center of Excellence CETEMPS, University of L'Aquila, L'Aquila, Italy

${ }^{9}$ Department of Physical and Chemical Sciences, University of L'Aquila, L'Aquila, Italy

${ }^{10}$ Facility for Airborne Atmospheric Measurements, Bedford, UK

${ }^{11}$ Department of Physics, University of Toronto, Toronto, Ontario, Canada

${ }^{12}$ National Centre for Atmospheric Science (NCAS), School of Environmental Sciences, University of East Anglia, Norwich, UK

${ }^{13}$ Department of Process Engineering and Applied Science, Dalhousie University, Halifax, Nova Scotia, Canada

${ }^{14}$ Institute of Arctic and Alpine Research, University of Colorado, Boulder CO, USA

${ }^{15}$ Atmospheric Chemistry Services, Okehampton, Devon, UK

${ }^{16}$ UK Meteorological Office, Exeter, UK

${ }^{17}$ School of Earth, Atmospheric and Environmental Sciences, University of Manchester, Manchester, UK

${ }^{18}$ Department of Physics and Astronomy, University of Leicester, Leicester, UK

${ }^{19}$ Department of Geological and Mining Engineering Sciences, Michigan Technological University, Houghton, MI, USA

${ }^{20}$ Global Modeling and Assimilation Office, NASA Goddard Space Flight Center, Greenbelt, MD, USA

* now at: National Centre for Atmospheric Science (NCAS), Department of Chemistry, University of York, York, UK

** now at: Department of Chemistry \& Biochemistry, Old Dominion University, Norfolk VA, USA

Correspondence to: P. I. Palmer (pip@ed.ac.uk)

Received: 12 December 2012 - Published in Atmos. Chem. Phys. Discuss.: 14 February 2013

Revised: 24 May 2013 - Accepted: 26 May 2013 - Published: 1 July 2013

\begin{abstract}
We describe the design and execution of the BORTAS (Quantifying the impact of BOReal forest fires on Tropospheric oxidants over the Atlantic using Aircraft and Satellites) experiment, which has the overarching objective of understanding the chemical aging of air masses that contain the
\end{abstract}

emission products from seasonal boreal wildfires and how these air masses subsequently impact downwind atmospheric composition. The central focus of the experiment was a twoweek deployment of the UK BAe-146-301 Atmospheric Research Aircraft (ARA) over eastern Canada, based out of 
Halifax, Nova Scotia. Atmospheric ground-based and sonde measurements over Canada and the Azores associated with the planned July 2010 deployment of the ARA, which was postponed by 12 months due to UK-based flights related to the dispersal of material emitted by the Eyjafjallajökull volcano, went ahead and constituted phase A of the experiment. Phase B of BORTAS in July 2011 involved the same atmospheric measurements, but included the ARA, special satellite observations and a more comprehensive groundbased measurement suite. The high-frequency aircraft data provided a comprehensive chemical snapshot of pyrogenic plumes from wildfires, corresponding to photochemical (and physical) ages ranging from $<1$ day to $\gtrsim 10$ days, largely by virtue of widespread fires over Northwestern Ontario. Airborne measurements reported a large number of emitted gases including semi-volatile species, some of which have not been been previously reported in pyrogenic plumes, with the corresponding emission ratios agreeing with previous work for common gases. Analysis of the $\mathrm{NO}_{\mathrm{y}}$ data shows evidence of net ozone production in pyrogenic plumes, controlled by aerosol abundance, which increases as a function of photochemical age. The coordinated ground-based and sonde data provided detailed but spatially limited information that put the aircraft data into context of the longer burning season in the boundary layer. Ground-based measurements of particulate matter smaller than $2.5 \mu \mathrm{m}\left(\mathrm{PM}_{2.5}\right)$ over Halifax show that forest fires can on an episodic basis represent a substantial contribution to total surface $\mathrm{PM}_{2.5}$.

\section{Introduction}

The Quantifying the impact of BOReal forest fires on Tropospheric oxidants over the Atlantic using Aircraft and Satellites (BORTAS) experiment was conducted during JulyAugust 2010 and 2011 (phases A and B, respectively), and was funded by the UK Natural Environmental Research Council, with meteorological field support from the UK Meteorological Office and Environment Canada. The overarching objective of BORTAS was to better understand the chemical evolution of plumes emitted from the burning of biomass, with a particular emphasis on the net production of tropospheric ozone $\left(\mathrm{O}_{3}\right)$ and downwind impacts on air quality. Our sub-objectives include (i) sampling biomass burning outflow from boreal North America over the western boundary of the North Atlantic during summer 2011 using the UK BAe-146-301 Atmospheric Research Aircraft; (ii) describing observed chemistry within plumes by using the measurements to constrain a near-explicit chemical mechanism, with particular attention to the $\mathrm{NO}_{\mathrm{y}}$ and organic chemistry; (iii) deriving a reduced chemical mechanism suitable for a global chemistry transport model (CTM) that accurately describes chemistry within the plumes; (iv) quantifying the impact of boreal forest fires on oxidant chemistry over the temperate and subtropical Atlantic using a nested 3-D CTM, driven by a reduced version of the near-explicit chemical mechanism and by assimilated field measurements; and (v) detecting, validating and quantifying the impact of boreal biomass burning on global tropospheric composition using data from space-borne sensors. To address these objectives, BORTAS integrated a number of concurrent activities: (1) airborne in situ measurements; (2) space-borne measurements; (3) balloon, ground-based in situ and remote-sensed measurements in Canada and the Azores; (4) near-explicit tropospheric chemical modelling; (5) regional and global chemistry transport models; and (6) inverse models. This paper provides an overview of BORTAS-B with an emphasis on the summer measurement campaign; BORTAS-A was described by Parrington et al. (2012).

Over the past $20 \mathrm{yr}$ (1990-2011), Canadian forest fires have burned a median of 1.7 million hectares $\mathrm{yr}^{-1}$, ranging from 626000 hectares in 2001 to over 7 million hectares in 1995 (data from Natural Resources Canada), with a year-toyear variability partly explained by large-scale changes in climate (e.g. the El Niño-Southern Oscillation). Although this is a small fraction of the forested land $(0.1-1.8 \%)$, it represents a substantial input of carbonaceous material and trace gases released to the atmosphere. The predominant tree species (by volume) include coniferous spruce (53\%), pine $(9 \%)$, and broadleaf poplar (12\%), which determine the distribution of natural emission of biogenic volatile organic compounds but also the release of volatiles as part of pyrolysis associated with forest fire (Drysdale, 2008).

Tropospheric $\mathrm{O}_{3}$ is a regulated secondary air pollutant because at elevated concentrations it is linked with human respiratory illness and damage to vascular plants with implications for food production and biogeochemical cycling. A considerable body of work has shown that long-range transport of $\mathrm{O}_{3}$ and its photochemical precursors can represent a significant contribution to background $\mathrm{O}_{3}$ over downwind continents and in some circumstances result in an increased number of days that exceed the regulated threshold concentration. The role of seasonal wildfires on this longrange transport of pollution remains unclear, partly because of its large year-to-year variability and partly because there remains substantial uncertainty in our understanding of the chemistry within these plumes. The primary focus of BORTAS is to understand the production and loss of $\mathrm{O}_{3}$ within plumes emitted from boreal forest fires as they are transported across the North Atlantic towards Europe.

Figure 1 shows a simplified schematic of the general atmospheric chemical system (Atkinson and Arey, 2003) that is the focus of BORTAS. We start on the left-hand side with an emitted volatile organic compound (VOC) being oxidized by a common atmospheric oxidant $\mathrm{OH}, \mathrm{NO}_{3}$ or $\mathrm{O}_{3}$, resulting in the production of an alkyl radical $\mathrm{R}$ that rapidly reacts with molecular oxygen to form peroxy radicals $\left(\mathrm{HO}_{2}, \mathrm{RO}_{2}\right)$. The fate of peroxy radicals depends on the photochemical environment. In a pyrogenic environment, where levels of 


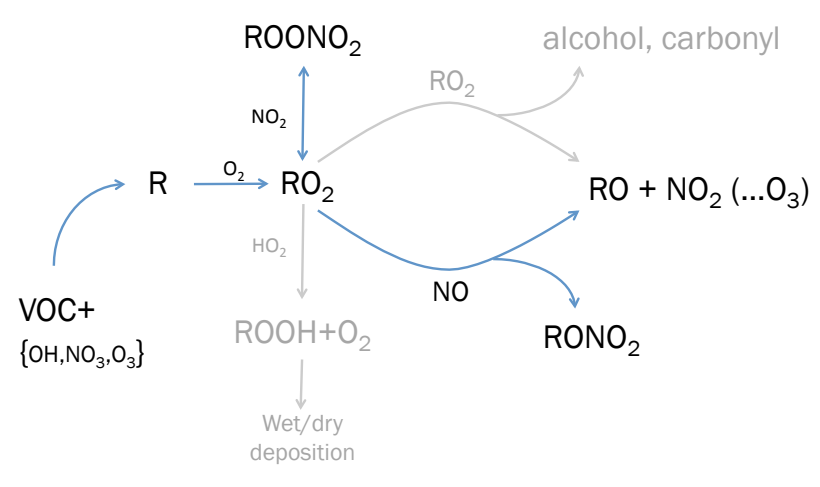

Fig. 1. A schematic of the atmospheric chemical system studied within BORTAS (Atkinson and Arey, 2003).

nitrogen oxides $\left(\mathrm{NO}+\mathrm{NO}_{2}=\mathrm{NO}_{\mathrm{x}}\right)$ are significantly elevated above ambient concentrations, $\mathrm{RO}_{2}$ typically proceeds via the $\mathrm{RO}_{2}+\mathrm{NO}$ and $\mathrm{RO}_{2}+\mathrm{NO}_{2}$ routes. $\mathrm{RO}_{2}+\mathrm{NO}$ proceeds via two channels resulting in the production of alkyl nitrates $\left(\mathrm{RONO}_{2}\right)$ and/or the production of $\mathrm{RO}$ and $\mathrm{NO}_{2}$, which can lead to the formation of $\mathrm{O}_{3}$ via $\mathrm{NO}_{2}$ photolysis. $\mathrm{RO}_{2}+\mathrm{NO}_{2}$ can also lead to the formation of $\mathrm{ROONO}_{2}$. Here, we focus on the peroxy acyl nitrates, where $\mathrm{RO}_{2}$ is $\mathrm{R}^{\prime} \mathrm{C}(\mathrm{O}) \mathrm{OO}$. Peroxy acyl nitrates are thermally stable at temperatures lower than $<263 \mathrm{~K}$, typical of the free and upper troposphere, resulting in an atmospheric lifetime of months so that it can be transported over long distances; in contrast, their lifetime in the lower troposphere $(>287 \mathrm{~K}$ ) is minutes to hours. The most abundant peroxy acyl nitrates in the troposphere are peroxyacetyl nitrate ( $\mathrm{PAN}, \mathrm{CH}_{3} \mathrm{C}(\mathrm{O}) \mathrm{O}_{2} \mathrm{NO}_{2}$ ) and peroxypropionyl nitrate ( $\mathrm{PPN}, \mathrm{CH}_{3} \mathrm{CH}_{2}(\mathrm{O}) \mathrm{O}_{2} \mathrm{NO}_{2}$ ), with PAN representing $75-90 \%$ of the total PAN concentration. PAN is effectively a thermally controlled reservoir for reactive nitrogen, delaying subsequent chemistry. Previous studies have shown that $\mathrm{RO}_{2}+\mathrm{HO}_{2}$ is still a significant sink of $\mathrm{RO}_{2}$ in a pyrogenic environment, producing peroxides $\left(\mathrm{H}_{2} \mathrm{O}_{2}\right.$ and hydroperoxides, $\mathrm{ROOH}$ ), with $\mathrm{H}_{2} \mathrm{O}_{2}$ readily removed by wet deposition. $\mathrm{ROOH}$, which is much less soluble than $\mathrm{H}_{2} \mathrm{O}_{2}$, has an atmospheric lifetime of 2-3 days and can produce alkoxy radicals (via photolysis) and aldehydes and recycle $\mathrm{RO}_{2}$ via $\mathrm{OH}$ oxidation. A recent review of chemistry measurements of pyrogenic plumes highlights that, based on the enhancement ratio of $\Delta \mathrm{O}_{3} / \Delta \mathrm{CO}$ (a common, brute-force metric for characterizing $\mathrm{O}_{3}$ production), there is no canonical theory of $\mathrm{O}_{3}$ chemistry within plumes (Jaffe and Wigder, 2012, and references therein; Monks et al., 2009, and references therein). This is not surprising given the combined effects of large variations in, for example, fuel type/loading, combustion efficiency (and subsequent emitted VOC amounts), meteorological and photochemical environments (e.g. convective energy, and aerosol and cloud characteristics), and the age of the measured plumes on the chemical system.
The impetus for BORTAS was a small number of pyrogenic air masses originating from Northern Canada and Alaska that were intercepted during the 2004 UK International Transport of Ozone and Precursors (ITOP) measurement campaign, which was part of the larger International Consortium for Atmospheric Research on Transport and Transportation (ICARTT). The main focus of ICARTT was to characterize the air quality over the North Atlantic, with an emphasis on long-range transport of anthropogenic pollution. The pyrogenic air masses were identified by a distinct distribution of primary chemical markers $(\mathrm{CO}$, ethene, acetlyene, and benzene), accompanied by elevated concentrations of PAN (Lewis et al., 2007). Analysis of these air masses revealed no robust relationship between $\mathrm{CO}$ and $\mathrm{O}_{3}$. In a case study, one pyrogenic plume, sampled at three different locations as it travelled across the North Atlantic, showed a net increase ( $17 \mathrm{ppb}$ ) in $\mathrm{O}_{3}$ and a concurrent decrease in $\mathrm{CO}$ over the five-day period. A Lagrangian model, used to understand the responsible chemical processes as the plume travelled over the North Atlantic, highlighted the role of aerosol in slowing both the production and loss of $\mathrm{O}_{3}$, but found the plume remained chemically active, mainly driven by the thermal decomposition of PAN as it descended through the free troposphere (Real et al., 2007). Real et al. (2007) also found that the model reproduced the change in $\Delta \mathrm{O}_{3} / \Delta \mathrm{CO}$ (negative to positive) over the North Atlantic, confirming that the change in $\mathrm{O}_{3}$ was due to photochemistry rather than dilution. The BAe-146 aircraft payload during BORTAS, described below, included instruments to better speciate the $\mathrm{NO}_{\mathrm{y}}$ budget and characterize aerosols, including semi-volatiles.

The NASA Arctic Research of the Composition of the Troposphere from Aircraft and Satellites (ARCTAS) 2008 campaign included a scientific objective on quantifying emissions from boreal forest fires and the near-field chemical evolution of the fire plumes (Jacob et al., 2010; Singh et al., 2010). During the spring (April) phase over Alaska, ARCTAS investigators intercepted Alaskan air masses (3-8 days old) and found evidence of $\mathrm{O}_{3}$ production, but during the summer phase (June-July) over Western Canada they sampled mainly young, near-field plumes ( $<1$ day) and evidence supporting net $\mathrm{O}_{3}$ production was inconclusive. During the summer phase they showed that $40 \%$ of the $\mathrm{NO}_{\mathrm{x}}$ was converted to PAN within a few hours of emission, thereby limiting the immediate reactivity within the plume (Alvarado et al., 2010). Model analyses of these data concluded that forest fire plumes have little impact on the median $\mathrm{O}_{3}$ profile over Canada (Alvarado et al., 2010). During BORTAS, owing to large-scale fires in Northwest Ontario, we were able to sample pyrogenic plumes with a range of photochemical ages, providing us with an excellent opportunity to better understand the photochemical aging processes within these plumes.

This paper describes the experimental design of the BORTAS-B airborne campaign, which was conducted during 12 July-3 August 2011. This includes an overview of 
BORTAS-B, incorporating a description of the fire activity and meteorology (Sect. 2) for the time period; a detailed description of the ground-based, airborne, and space-borne instruments that supported the BORTAS-B campaign (Sect. 3); and a description of first results (Sect. 4) from individual research groups from the BORTAS-B science team, including descriptions of the modelling strategies that are the subjects of individual papers. We conclude in Sect. 5.

\section{Campaign overview}

To determine the optimal time and location of the measurement campaign, we used the GEOS-Chem atmospheric chemistry transport model driven by NASA GEOS-5 reanalysis meteorology (Sect. 3.5) to study the atmospheric transport of year-specific biomass burning emissions over Canada, acknowledging substantial year-to-year variations in the emissions and transport pathways. Based on that analysis we identified late July as the period that would give us the largest probability of intercepting near-field (within Canada) and far-field (e.g. from boreal Asia) plumes. We also identified Halifax, Nova Scotia, as the optimal locus for our base of operations for the BAe-146 ARA, giving us access to long-range transported plumes at high latitudes and nearfield plumes that tend to remain close to the latitude of emission. As we discuss below, choosing Halifax also provided us with an opportunity to work with the ground-based measurement community, which greatly enhanced the originally planned science.

BORTAS has four major elements: the Canadian groundbased network, the BAe-146 Atmospheric Research Aircraft (ARA), satellite observations, and the computer modelling of atmospheric chemistry and transport, all of which contribute to the scientific objectives of the campaign and are discussed in detail below.

BORTAS was originally planned for summer 2010, but the BAe-146 ARA was grounded for civil contingency flying associated with the dispersal of volcanic aerosol from the eruption of Eyjafjallajökull (Dacre et al., 2012). We decided to run the campaign as planned (12 July-3 August 2010) but without the ARA, providing an important dryrun for the modelling and ground-based measurement teams; we hereinafter refer to this as Phase A of the campaign (BORTAS-A). Deployment of the ARA in 2011 during 12 July-3 August is Phase B of BORTAS (BORTAS-B) and is the main subject of this paper.

\subsection{Fire activity}

Figure 2 shows the time and location of active fires over the Northern Hemisphere during Phases A and B of BORTAS. In many respects, the number and distribution of July fires over high northern latitudes during 2010 were closer to climatological values than 2011, with the exception of fire ac- tivity over Russia. During 2011 there was substantially less burning over the Chukotka and Kamchatka federal subjects of Russia. Fires over Canada during BORTAS-B were comparatively early, with large wildfires near Richardson Backcountry and Slave Lake, Alberta, starting in May, which removed some of the combustible material in that area that would have typically burned later in the summer (see 2010 vs. 2011). BORTAS-B was largely characterized by a small number of large near-field fires over Northwestern Ontario which started and completed during the campaign and substantial far-field fires from boreal Asia. Tree species over this region include pine (Pinus banksiana, Pinus resinosa, Pinus strobus), spruce (Picea glauca, Picea mariana), poplar (Populus basalmifera), aspen (Populus grandidentata, Populus tremuloides), maple (Acer rubrum), fir (Abies balsamea), birch (Betula papyrifera), ash (Fraxinus nigra), and tamarack (Larix laricina).

\subsection{Meteorological overview for BORTAS-A and BORTAS-B}

Figure 3 shows the climatological mean (15 July-3 August, 1981-2010) vector winds in the free troposphere $(500 \mathrm{hPa})$ over North America and those fields corresponding to the BORTAS-A and BORTAS-B period, suggesting that pollutants will generally follow a west to east flow pattern, with a strong flow from NW Ontario often increasing in forward speed as the vector winds depart the east coast of North America and head toward the European continent. This feature of transport over the North Atlantic is regulated by the location and strength of the polar vortex and the mid-North Atlantic subtropical high.

Figure 4 shows that the mean daily accumulated precipitation during BORTAS-A was close to climatological values over Maritime Canada but drier than climatology across central Quebec and Ontario. During BORTAS-B precipitation was generally drier than climatology over Maritime Canada and across Western Canada. An example of the role of precipitation in the transport of pyrogenic aerosol during BORTAS-B is reported by Griffin et al. (2013) and Franklin et al. (2013).

Below, we present synoptic meteorological fields, interpreting them in terms of atmospheric flow, that occurred during the BORTAS-B field measurement intensive and discuss them in context with BORTAS-A and the climatological mean for the same period. Table 1 provides a brief description of the meteorology associated with each BORTAS-B flight.

\subsubsection{Mid-troposphere}

Figure 5a shows the climatological (1981-2010) midtropospheric flow $(500 \mathrm{hPa})$ for North America for the period 15 July-3 August, which is similar to the first two weeks of July and shows a trough over Hudson Bay across 
Table 1. Synoptic meteorology and weather associated with BORTAS flights over Canada.

\begin{tabular}{|c|c|c|}
\hline Flight \#, data & Sortie description & Synoptic meteorology \\
\hline B618, 12 July 2011 & Outbound transit 1: Cranfield, UK, to Horta, Azores & \\
\hline B618, 13 July 2011 & Outbound transit 2: Horta, Azores, to St John's, NL & \\
\hline B619, 13 July 2011 & Outbound transit 2: St John's, NL, to Halifax, NS & \\
\hline B620, 15 July 2011 & Halifax, NS-Quebec, NS-Halifax, NS & $\begin{array}{l}\text { Low from surface to } 500 \mathrm{hPa} \text { S of Sable Island. Weak ridge, lowest levels, } \\
\text { over northern Gulf and southern Labrador. Clouds over NS and } \\
\text { Prince Edward Island (PEI), otherwise clear. }\end{array}$ \\
\hline B621a, 18 July 2011 & Halifax, NS-Goose Bay, NL & Weak short wave trough crossing Maritime Canada; cold front crossing Nova. \\
\hline B621b, 18 July 2011 & Goose Bay, NL-Halifax, NS & $\begin{array}{l}\text { Scotia. Weak ridge building into S Labrador. Cloud and precipitation over } \\
\text { Newfoundland. Showers inland from the N shore of Gulf. Clearing skies for the return flight. }\end{array}$ \\
\hline B622, 20 July 2011 & Halifax, NS-Quebec City, QC & $\begin{array}{l}\text { Low from surface to } 500 \mathrm{hPa} \text { S Ungava Bay. Surface low and frontal wave moving E from } \\
\text { mouth of St Lawrence. Flight in "warm" sector - skies mainly clear. }\end{array}$ \\
\hline B623, 20 July 2011 & Quebec City, QC-Halifax & $\begin{array}{l}\text { Low from surface to } 500 \mathrm{hPa} \text { S Ungava Bay. Surface low and frontal wave just } \mathrm{N} \text { of Anticosti } \\
\text { Island and cold front west. Showers and thundershowers along and in advance of front. } \\
\text { Aircraft may have encountered showers over PEI. }\end{array}$ \\
\hline B624, 21 July 2011 & Halifax, NS-St John's, NL-Halifax, NS & $\begin{array}{l}\text { Low from surface to } 500 \mathrm{hPa} \text { over extreme N Labrador. Cold front from NB to S of NF (Newfoundland). Weak } \\
\text { low crossing NB late day. Cloud moved into flight zone from the west. Precipitation } \\
\text { for return flight from S of NF to Halifax. }\end{array}$ \\
\hline B625, 24 July 2011 & Halifax, NS, region & $\begin{array}{l}\text { Low from surface to } 500 \mathrm{hPa} \text { southern Davis Strait with trough to deepening low over NF moving } \\
\text { east. Cold front east of NF. Flight path in clear skies. }\end{array}$ \\
\hline B626, 26 July 2011 & Halifax, NS-Thunder Bay, ON & $\begin{array}{l}\text { Low from surface to } 500 \mathrm{hPa} \text { over extreme S QC. Ridge surface and aloft over NW ON. } \\
\text { Flight in clouds westbound over S QC. Showers likely below flight level. Clear skies in ON. }\end{array}$ \\
\hline B626, 26 July 2011 & Thunder Bay, ON, region & $\begin{array}{l}\text { As above for flight B } 626 \text { - Clear skies with convective clouds over NW ON. Some showers } \\
\text { late in-flight period. }\end{array}$ \\
\hline B627, 27 July 2011 & Thunder Bay, ON-Goose Bay, NL & $\begin{array}{l}\text { Weak ridging over Ontario, all levels, and weak trough Labrador to Maritimes. Cloud moving } \\
\text { into western Ontario. Clear over E ON and W QC. Cumulus over central QC and Labrador. }\end{array}$ \\
\hline B628a, 28 July 2011 & Goose Bay, NL, region & Weak ridge surface through to $500 \mathrm{hPa}$ central Labrador to NB. Mostly clear for flight route. \\
\hline B628b, 28 July 2011 & Goose Bay, NL-Halifax, NS & Cumulus and towering cumulus over higher terrain southern Labrador. \\
\hline B629, 31 July 2011 & Halifax, NS, region & $\begin{array}{l}\text { Trough from surface through to } 500 \mathrm{hPa} \text { along Labrador coast to low centre off south coast NF. Cooler } \\
\text { air mass over region. Weak ridge building over NB to W Labrador. Generally clear skies for } \\
\text { flight route and level. }\end{array}$ \\
\hline B630, 31 July 2011 & Halifax, NS, region & As above for Flight B629. \\
\hline $\begin{array}{l}\text { B631, } 2 \text { August } 2011 \\
\text { B631, } 3 \text { August } 2011\end{array}$ & $\begin{array}{l}\text { Halifax, NS, to Horta, Azores } \\
\text { Horta, Azores, to Cranfield, UK }\end{array}$ & $\begin{array}{l}\text { Return transit leg } 1 . \\
\text { Return transit leg } 2 .\end{array}$ \\
\hline
\end{tabular}

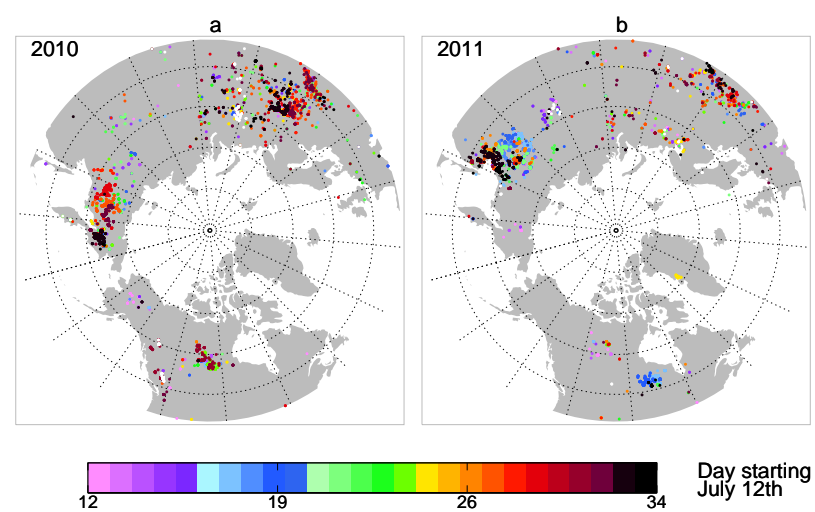

Fig. 2. Time and location of active fires during 12 July-3 August 2010 (a) and 2011 (b), informed by the ATSR radiance measurements (Mota et al., 2006). The colour denotes the day number, starting on 12 July. ATSR fire count data are from ATSR-WFA, from the Data User Element of the European Space Agency.
Quebec to Greenland and Iceland. Figure 5d shows that the 2010 flow was similar to the climatological pattern with only weak positive anomalies in height over North America and stronger positive anomalies with ridging off the west coast of Canada and over European Russia and far eastern Siberia and Kamchatka. This is in contrast to the BORTAS-B period in Fig. $5 g$, with strong positive anomalies in geopotential height over the upper Mississippi, the North Pacific and a dramatic positive height anomaly over eastern Siberia. A positive anomaly also lies over the mid-North Atlantic, covering all of Greenland, possibly resulting in a more northerly route for the North Atlantic transport to the European continent. Labrador and Maritime Canada had negative anomalies along with Alaska and British Columbia. The Maritime Canada negative anomaly is indicative of the cooler and cloudy weather that occurred during BORTAS-B. 
a

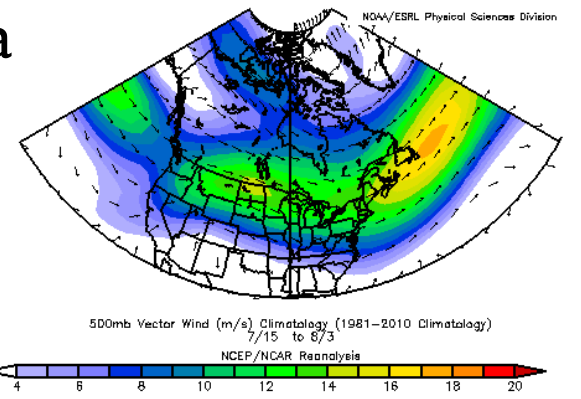

b

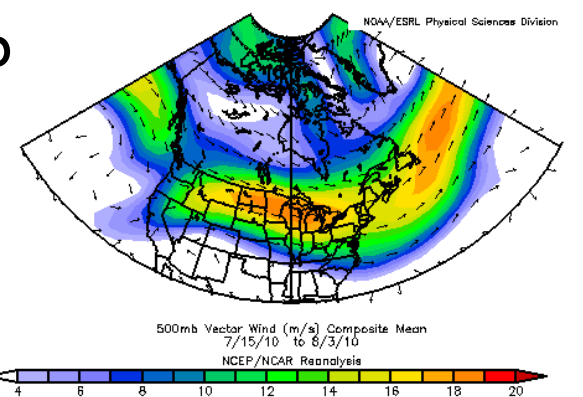

c

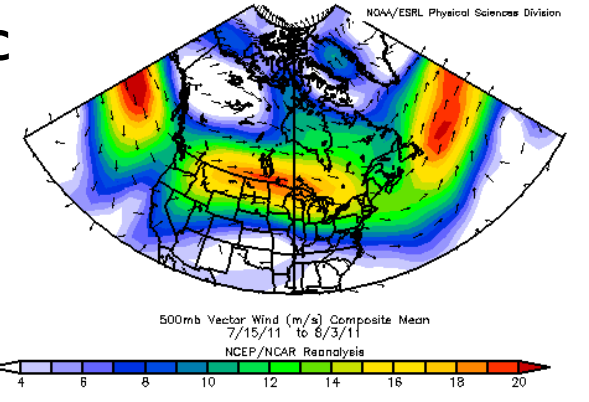

\section{$500 \mathrm{hPa}$ vector wind}

Fig. 3. Climatological mean $500 \mathrm{hPa}$ wind vector $\left(\mathrm{m} \mathrm{s}^{-1}\right)$ over North America for 15 July-3 August for the period 1981-2010 (a), and the corresponding departure of those means for 15 July-3 August 2010 (b) and for 15 July-3 August 2011 (c). Image provided by the NOAA/ESRL Physical Science Division, Boulder, Colorado (http://www.esrl.noaa.gov/psd/data/composites/day).

\subsubsection{Lower troposphere}

Figure $5 \mathrm{~b}$ shows the climatological mean $850 \mathrm{hPa}$ surface during the BORTAS period. The pattern maintains ridging over the NE Pacific, the subtropical anticyclone over the mid-North Atlantic, with a minor trough from a low in the northern Davis Strait to the northern Labrador Sea. Figure 5e shows that the anomaly for 2010 has a strong positive variation over the NE Pacific and a weak negative variation over central Quebec with an extension to Northwestern Ontario and just south of Newfoundland and east of Nova Scotia. Figure 5h shows that for 2011 there are stronger negative anomalies to the southeast of Nova Scotia, south of Sable
Island with a trough to Hudson Bay then extending west to northern Saskatchewan to the upper Mackenzie Valley and Yukon. A slight positive anomaly lay to the south of the Great Lakes, again indicative of the surface and upper ridging that favoured the development of forest fires in Northwestern Ontario.

\subsubsection{Surface}

Figure $5 \mathrm{c}$ shows the climatological mean sea level pattern over North America for the BORTAS period, which shows a weak pressure pattern with a few isobars due to continued ridging associated with the subtropical anticyclone off the western North Atlantic and the ridge over the northeast Pacific, and a low over Baffin Island with a weak trough to the central and western US. Figure 5f shows that the anomaly pattern for 2010 has a strong high over the northeast Pacific off British Columbia and a low pressure area south of Newfoundland with a trough to Northwestern Ontario and then along the tree line to Great Slave Lake, Northwest Territories. Figure 5i shows a more dramatic anomaly pattern in 2011 with lower pressure south of Newfoundland and east of Nova Scotia, a low on southern Baffin Island and a significant negative anomaly over Yukon and Northwest Territories to Northwestern Ontario. A potential result of the pattern for 2011 is that more synoptic low pressure systems transited from west to east than is the norm. In summary, the surface synoptic pattern for 2011 commenced with an area of high pressure in the earlier portion of the study, then quickly gave way to the intrusion of frontal troughs, weak low pressure systems and shifts of wind from the southwest to the west and northwest. A respite from this dynamic pattern occurred on 29 July as a short-lived ridge moved across Atlantic Canada.

\section{BORTAS-B measurements}

\subsection{BAe-146 aircraft payload and deployment}

The BAe-146 aircraft has an endurance of approximately $5.5 \mathrm{~h}$ with a full science payload ( 4.2 tons) and has a science speed of 200 knots calibrated airspeed $\left(103 \mathrm{~m} \mathrm{~s}^{-1}\right.$ CAS), resulting in a standard air range of approximately $2000 \mathrm{~km}$ at sea level, increasing to $3300 \mathrm{~km}$ at a typical maximum working standard pressure altitude (sHp) of $30000 \mathrm{ft}(9.1 \mathrm{~km})$; for A-to-A flights with varying altitudes and time on station, this typically gave a working radius of about $900 \mathrm{~km}$, and for A-to-B science flights a range of about $1800 \mathrm{~km}$. Table 2 shows the BAe-146 instrument payload during BORTAS-B, including the averaging times for each instrument. The payload reflects the core science objectives of characterizing the chemical processing of pyrogenic air masses with measurements of total alkyl nitrates, total peroxy nitrates, total $\mathrm{NO}_{\mathrm{y}}$, $\mathrm{NO}, \mathrm{NO}_{2}$, and PAN.

Before entering the BORTAS in-theatre domain, the aircraft transited from Cranfield UK (where it is based) to 

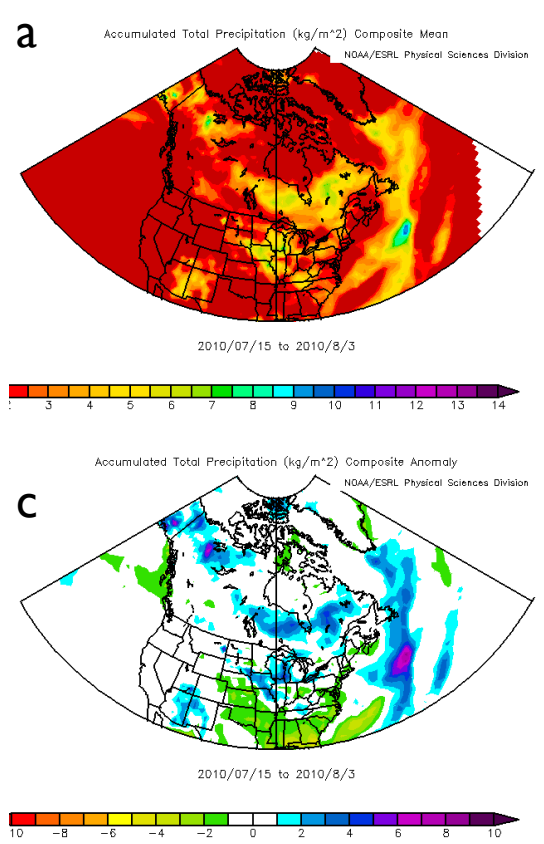

BORTAS-A

I5/7- 3/8, 2010 b
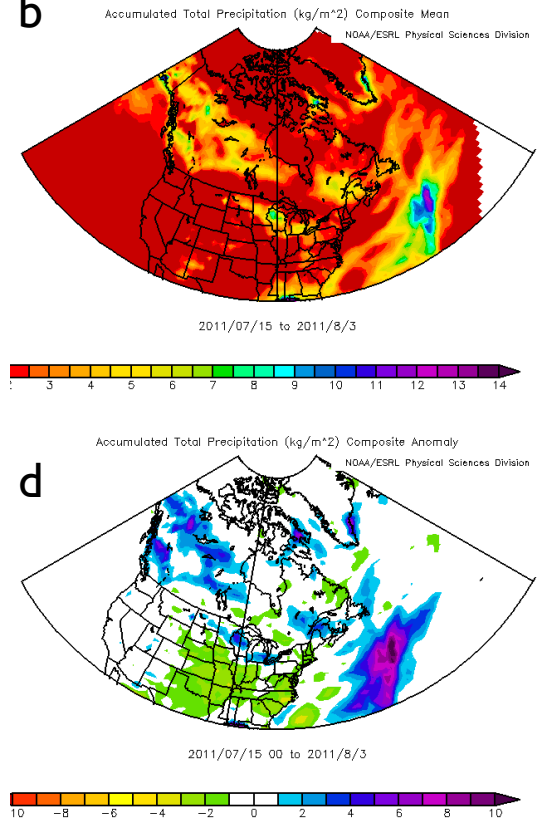

BORTAS-B

$|5 / 7-3 / 8,201|$

Fig. 4. Daily mean accumulated precipitation $\left(\mathrm{kg} \mathrm{m}^{-2}\right)$ over North America for 15 July-3 August, 2010 (a) and 2011 (b), and the associated anomalies for 2010 (c) and 2011 (d) with respect to the 1981-2010 climatological mean. Image provided by the NOAA/ESRL Physical Science Division, Boulder, Colorado (http://www.esrl.noaa.gov/psd/data/composites/day).

Horta, Azores, on 12 July 2011; from Horta, Azores, to St John's, Newfoundland, on 13 July 2011; and from St John's, Newfoundland, to Halifax on 13 July 2011. Figure 6 shows the 13 non-transit BORTAS-B flights and the location of active ozonesonde launch sites (Table 3) and Along-Track Scanning Radiometer (ATSR) fire counts. With the exception of flight B624 when there was no Thermal Dissociation Laser Induced Fluorescence (TD-LIF) $\mathrm{NO}_{\mathrm{y}}$ data, all instruments were operational and reported data for all flights shown. Table 1 summarizes each BORTAS-B flight, including outbound and inbound transit legs; a total of $77 \mathrm{~h}, 28 \mathrm{~min}$, and $33 \mathrm{~s}$. The BAe-146 spent most of the time sampling in the free troposphere, with more than a third of the time between 6 and $9 \mathrm{~km}$.

\subsection{Dalhousie Ground Station (DGS) and additional Canadian sites}

Wherever possible we coordinated surface measurements with the BORTAS-B aircraft deployment to improve understanding of the transport of pyrogenic plumes as they travelled over Canada. The DGS represents a coordinated measurement activity conducted at a height of $65 \mathrm{~m}$ above mean sea level on the roof of the Sir James Dunn building at Dalhousie University $\left(44.64^{\circ} \mathrm{N}, 63.59^{\circ} \mathrm{W}\right)$, including investigators from Dalhousie University, Environment Canada, Uni- versity of Toronto, and University of Sherbrooke. Table 4 summarizes the individual instruments that participated in the DGS activity during BORTAS-B. BORTAS flight B623 explicitly included profile measurements around the DGS. Some of the DGS scientific activities are briefly discussed below.

The University of Toronto Atmospheric Observatory (TAO), located at $43.66^{\circ} \mathrm{N}, 79.40^{\circ} \mathrm{W}$ and 174 ma.s.l. on the 16th floor of the Burton Tower of the McLennan Physical Laboratories in downtown Toronto, included in particular an ABB Bomem DA8 FTIR Spectrometer (Wiacek et al., 2007) similar to the instrument housed at Dalhousie University. Work within BORTAS-B led by DGS investigators has found instances where pyrogenic plume pass over both the TAO and DGS, providing an opportunity to study the chemical evolution of a plume (Griffin et al., 2013; Franklin et al., 2013).

Coordinated additional launches of ozonesondes, in collaboration with Environment Canada, were used to help characterize the vertical distribution of $\mathrm{O}_{3}$ associated with pyrogenic plumes. Table 3 shows the key launch sites during BORTAS-B; for interest, Table 3 also shows the corresponding launches for 2010 which were supporting another measurement intensive to understand stratosphere-troposphere exchange (Bourqui et al., 2012). The 2010 ozonesonde data 

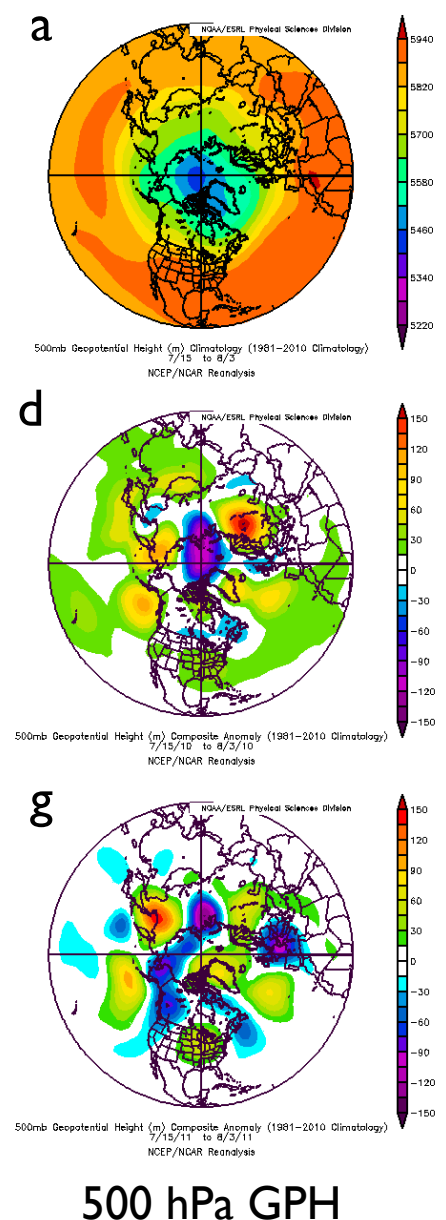

b

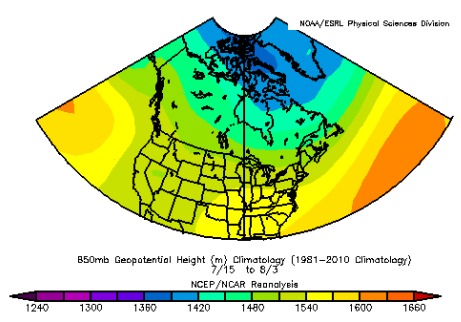

e

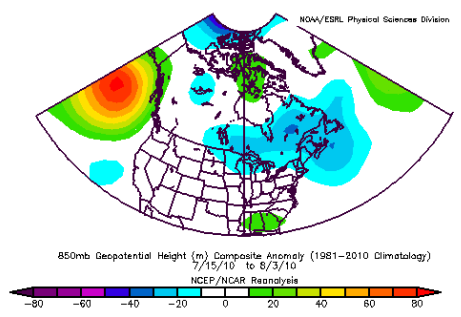

h

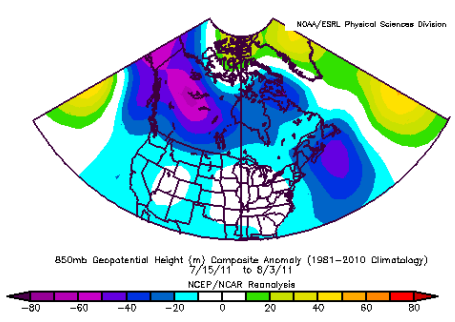

850 hPa GPH
C

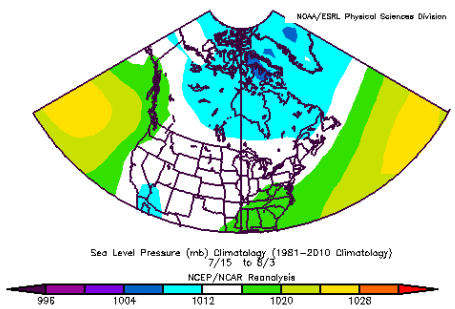

f

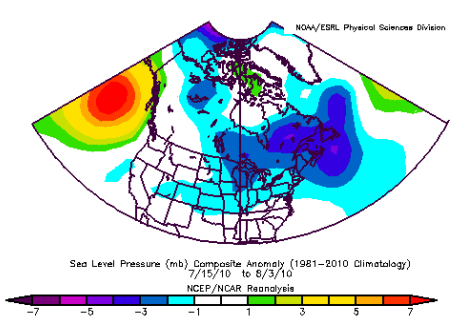

i

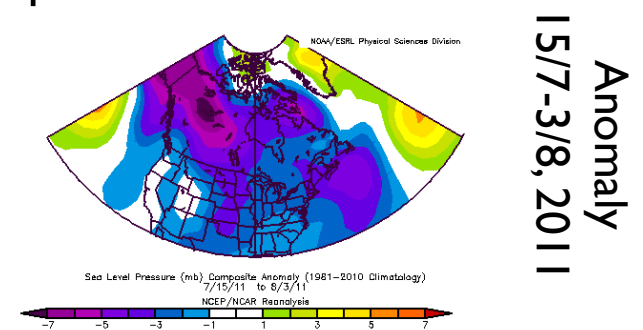

Sea level pressure

Fig. 5. Climatological mean $500 \mathrm{hPa}$ (a) and $850 \mathrm{hPa}$ (b) geopotential heights (GPH, expressed in metres, m) and sea level pressure (mb) (c) for 15 July-3 August for the period 1979-1995, and the corresponding departures from those means for 15 July-3 August 2010 (d-f) and for 15 July-3 August 2011 (g-i). Image provided by the NOAA/ESRL Physical Science Division, Boulder, Colorado (http://www.esrl.noaa. gov/psd/data/composites/day).

were used to help evaluate the GEOS-Chem atmospheric chemistry transport model (Parrington et al., 2012) as part of modelling activities supporting BORTAS-B.

BORTAS investigators also used data from the Canadian Operational Research Aerosol LiDAR Network (CORALNet) led by Environment Canada (Strawbridge, 2013), with sites at Egbert (Ontario), Sherbrooke (Quebec) and Acadia (Nova Scotia). These sites were chosen to monitor transport events as well as to investigate regional air quality issues. For further information about the LiDAR technology, the reader is referred to Strawbridge (2013).

\subsection{Pico Mountain Atmospheric Research Observatory}

The Pico Mountain Atmospheric Research Observatory (also known as PICO-NARE) is located in the Azores, Portugal $\left(38^{\circ} 28.226^{\prime \prime} \mathrm{N}, 28^{\circ} 24.235^{\prime \prime} \mathrm{W}, 2225\right.$ ma.s.1.). Its geographical location makes it ideal to study the long-range free-tropospheric transport of pyrogenic plumes from boreal North America (Honrath et al., 2004), and provides us with an opportunity to study aged plumes after they have travelled partway across the North Atlantic. Table 5 shows the measurements taken during BORTAS phases A and B. As part of the outbound and inbound transit flights, the BAe-146 ARA encircled PICO-NARE in an attempt to cross-calibrate similar measurements. During July 2011 the atmospheric flow over the North Atlantic downwind of the BORTAS-B measurements was such that variations of $\mathrm{CO}$ at Pico from Canadian pyrogenic sources were not as prominent as in recent previous years.

\subsection{Satellite observations}

Validating space-borne observations associated with wildfires was a core scientific objective of BORTAS-B, allowing us to relate the relatively small-scale data from the BAe-146 
Table 2. BAe-146 payload during BORTAS.

\begin{tabular}{|c|c|c|c|c|}
\hline $\begin{array}{l}\text { Species/ } \\
\text { parameter }\end{array}$ & Method & $\begin{array}{l}\text { Averaging } \\
\text { time }\end{array}$ & $\begin{array}{l}\text { Precision/ } \\
\text { accuracy }\end{array}$ & $\begin{array}{l}\text { Reference/ } \\
\text { affiliation }\end{array}$ \\
\hline Position, winds, $u, v, w$ & INS, GPS, 5-port turbulence probe & $0.1 \mathrm{~s}$ & $0.01 \Delta P / P_{S}$ & FAAM, Petersen and Renfrew (2009) \\
\hline Relative humidity & Hygrometer, General Eastern 1011b & $4 \mathrm{~Hz}$ & $\begin{array}{l} \pm 0.5- \pm 3 \mathrm{~K} \text { dependent on } \\
\text { dew point and ambient conditions }\end{array}$ & FAAM, Ström et al. (1994) \\
\hline Temperature & $\begin{array}{l}\text { Rosemount Aerospace Ltd. } \\
\text { sensor } 102 \mathrm{AL}\end{array}$ & $32 \mathrm{~Hz}$ & $\pm 0.3 \mathrm{~K}$ & FAAM, Lenschow (1986) \\
\hline $\mathrm{CO}$ & VUV resonance/fluorescence & $1 \mathrm{~s}$ & $1 \mathrm{ppb}, 3 \%$ & FAAM, Gerbig et al. (1999). \\
\hline $\mathrm{CO}_{2}, \mathrm{CH}_{4}$ & $\begin{array}{l}\text { Cavity enhanced absorption } \\
\text { spectrometer }\end{array}$ & $1 \mathrm{~s}$ & $\begin{array}{l}\text { At } 1 \mathrm{~Hz} \text { : } \\
2.5 \mathrm{ppb} \text { for } \mathrm{CH}_{4} \text { and } \\
0.5 \mathrm{ppm} \text { for } \mathrm{CO}_{2}\end{array}$ & O'Shea et al. (2012), FAAM \\
\hline $\mathrm{O}_{3}$ & UV absorption & $3 \mathrm{~Hz}$ & $1 \mathrm{ppb}, \pm 5 \%$ & FAAM, Wilson and Birks (2006) \\
\hline $\mathrm{HCN}, \mathrm{HCOOH}, \mathrm{N}_{2} \mathrm{O}_{5}$ & $\begin{array}{l}\text { Chemical Ionisation Mass } \\
\text { Spectrometer (CIMS) }\end{array}$ & & $26 \mathrm{ppt}$ & U. Manchester \\
\hline $\begin{array}{l}\mathrm{NO}_{2}, \sum \mathrm{RO}_{2} \mathrm{NO}_{2} \\
\sum \mathrm{RONO}_{2}, \mathrm{NO}_{\mathrm{y}}\end{array}$ & $\begin{array}{l}\text { Thermal Dissociation Laser } \\
\text { Induced Fluorescence (TD-LIF) }\end{array}$ & $10 \mathrm{~Hz}$ & $\begin{array}{l}10 \%, 22 \%, 34 \%, \text { and } 46 \% \\
\text { for } \mathrm{NO}_{2}, \sum \mathrm{PNs}^{\sum \mathrm{ANs} \text {, and } \mathrm{NO}_{\mathrm{y}} \text {, respectively }}\end{array}$ & $\begin{array}{l}\text { Dari-Salisburgo et al. (2008), } \\
\text { CETEMPS, Department of Physical and } \\
\text { Chemical Sciences, University of L'Aquila, Italy }\end{array}$ \\
\hline $\mathrm{C}_{5}-\mathrm{C}_{12}$ VOCs & $\begin{array}{l}\text { GC-MS (Gas Chromatography } \\
\text { Mass Spectrometry) }\end{array}$ & $180 \mathrm{~s}$ & $\begin{array}{l}\text { Species dependent, } \\
\text { typically } 10 \text { ppt }(20 \%)\end{array}$ & $\begin{array}{l}\text { Purvis et al. (2013), } \\
\text { U. York }\end{array}$ \\
\hline $\begin{array}{l}\mathrm{C}_{2}-\mathrm{C}_{7} \mathrm{NMHCs} \text {, acetone } \\
\mathrm{CH}_{3} \mathrm{OH}\end{array}$ & WAS-GC & 30 s fill time & $\begin{array}{l}\text { Species dependent, } \\
\text { typically } 1-5 \text { ppt (5\%) }\end{array}$ & $\begin{array}{l}\text { Hopkins et al. (2003), } \\
\text { U. York }\end{array}$ \\
\hline $\begin{array}{l}\mathrm{CH}_{3} \mathrm{CN}, \mathrm{C}_{3} \mathrm{H}_{6} \mathrm{O} \\
\mathrm{C}_{5} \mathrm{H}_{8}, \mathrm{MVK}+\mathrm{MACR}, \\
\mathrm{C}_{4} \mathrm{H}_{8} \mathrm{O}, \mathrm{C}_{6} \mathrm{H}_{6} \\
\mathrm{C}_{7} \mathrm{H}_{8}, \mathrm{C}_{10} \mathrm{H}_{16}\end{array}$ & $\begin{array}{l}\text { PTR-MS } \\
\text { (Proton Transfer } \\
\text { Reaction Mass Spectrometer) }\end{array}$ & $1 \mathrm{~s}$ & $\begin{array}{l}37,95,120,59 \\
61,45,109,148 \text { ppt, respectively. } \\
\text { Mean of the precision } \\
\text { estimates over all } \\
\text { BORTAS flights. }\end{array}$ & Murphy et al. (2010) \\
\hline $\mathrm{NO}, \mathrm{NO}_{2}$ & $\begin{array}{l}\text { Chemiluminescence, single-channel, } \\
\text { Air Quality Design Inc }\end{array}$ & $10 \mathrm{~s}$ & $10 \mathrm{ppt}$ & FAAM, Lee et al. (2009), Reidmiller et al. (2010) \\
\hline PAN & Dual column GC-ECD & $90 \mathrm{~s}$ & $3 \%, 10 \%$ & Whalley et al. (2004) \\
\hline $\begin{array}{l}\text { Non-refractory aerosol } \\
\text { composition, } 40-700 \mathrm{~nm} \\
\text { vacuum aerodynamics diameter }\end{array}$ & AMS & $\begin{array}{l}\text { LOD* }^{*} \text { : } \\
3 \mathrm{ng} \mathrm{m}^{-3} \text { for nitrate and sulfate; } \\
25 \mathrm{ng} \mathrm{m}^{-3} \text { for organics; and } \\
30 \mathrm{ngm}^{-3} \text { for ammonium. } \\
\text { Precisions same as LOD. } \\
\text { Accuracy: } 20 \%\end{array}$ & $15-150 \mathrm{ng} \mathrm{m}^{-3}$ & Jayne et al. (2000) \\
\hline $\begin{array}{l}\text { Refractory black carbon, } \\
70-520 \mathrm{~nm}\end{array}$ & SP2 & $\begin{array}{l}\text { Accuracy } 20 \% \text {, precision } 5 \% \text { at } 5 \mathrm{~s} \\
\text { average }\end{array}$ & & \\
\hline $\mathrm{jNO}_{2}, \mathrm{jO}^{1} \mathrm{D}$ & Fixed bandwidth radiometry, $0.3-3.0 \mu \mathrm{m}$ & $1 \mathrm{~Hz}$ & $5.5 \%$ & $\begin{array}{l}\text { Junkermann et al. (1989), } \\
\text { Volz-Thomas et al. (1996), } \\
\text { McConnell et al. (2010) }\end{array}$ \\
\hline
\end{tabular}

* Limit of detection (LOD) is based on a $30 \mathrm{~s}$ average, assuming a collection efficiency of 0.5 .

Table 3. Environment Canada ozonesonde launch sites during BORTAS phases A (2010) and B (2011).

\begin{tabular}{|c|c|c|}
\hline Site & BORTAS-A launches ${ }^{1}$ & BORTAS-B launches 2 \\
\hline Alert, Nunavut $\left(82^{\circ} \mathrm{N}, 62^{\circ} \mathrm{W}\right)$ & 1 & 1 \\
\hline Bratt's Lake, Saskatchewan $\left(50^{\circ} \mathrm{N}, 105^{\circ} \mathrm{W}\right)$ & 18 & 20 \\
\hline Churchill, Manitoba $\left(59^{\circ} \mathrm{N}, 94^{\circ} \mathrm{W}\right)$ & 1 & - \\
\hline Egbert, Ontario $\left(44^{\circ} \mathrm{N}, 80^{\circ} \mathrm{W}\right)$ & 16 & 15 \\
\hline Eureka, Nunavut $\left(80^{\circ} \mathrm{N}, 86^{\circ} \mathrm{W}\right)$ & 2 & 2 \\
\hline Goose Bay, Newfoundland $\left(53^{\circ} \mathrm{N}, 60^{\circ} \mathrm{W}\right)$ & 20 & 20 \\
\hline Kelowna, British Columbia $\left(50^{\circ} \mathrm{N}, 119^{\circ} \mathrm{W}\right)$ & 2 & 2 \\
\hline Montreal, Quebec $\left(45^{\circ} \mathrm{N}, 73^{\circ} \mathrm{W}\right)$ & 19 & - \\
\hline Resolute, Nunavut $\left(75^{\circ} \mathrm{N}, 95^{\circ} \mathrm{W}\right)$ & 2 & 1 \\
\hline Sable Island, Nova Scotia $\left(44^{\circ} \mathrm{N}, 60^{\circ} \mathrm{W}\right)$ & 19 & 19 \\
\hline Stony Plain (Edmonton), Alberta $\left(54^{\circ} \mathrm{N}, 114^{\circ} \mathrm{W}\right)$ & 2 & 2 \\
\hline Walsingham, Ontario $\left(43^{\circ} \mathrm{N}, 81^{\circ} \mathrm{W}\right)$ & 14 & - \\
\hline Yarmouth, Nova Scotia $\left(44^{\circ} \mathrm{N}, 66^{\circ} \mathrm{W}\right)$ & 19 & 20 \\
\hline
\end{tabular}

${ }^{1} 12$ July-3 August 2010.

2 July-3 August 2011. 
Table 4. Ground-based measurements at the Dalhousie Ground Station during BORTAS.

\begin{tabular}{|c|c|c|}
\hline Parameters & Instrument & Reference/affiliation \\
\hline Weather station & $\begin{array}{l}\text { Temperature, dew point temperature, relative humidity, } \\
\text { wind direction and speed, rain amount, } \\
\text { barometric pressure }\end{array}$ & Environment Canada \\
\hline $\begin{array}{l}\text { Profiles of aerosol } \\
\text { and cloud extinction }\end{array}$ & $\begin{array}{l}\text { Raman LiDAR, Nd:YAG laser } \\
\text { pulsing at } 532 \mathrm{~nm} \text { at } 20 \mathrm{~Hz}\end{array}$ & $\begin{array}{l}\text { Dalhousie University, } \\
\text { Bitar et al. (2010) }\end{array}$ \\
\hline $\begin{array}{l}\text { Partial columns of } \mathrm{CO}, \mathrm{CH}_{4}, \mathrm{~N}_{2} \mathrm{O} \text {, } \\
\mathrm{C}_{2} \mathrm{H}_{6} \text {, and } \mathrm{O}_{3}\end{array}$ & $\begin{array}{l}\text { Dalhousie Atmospheric Observatory ABB Bomem } \\
\text { DA8 FTIR Spectrometer measuring } 750-4300 \mathrm{~cm}^{-1} \\
\text { with a resolution of } 0.004 \mathrm{~cm}^{-1}\end{array}$ & Dalhousie University \\
\hline Black carbon & Two-wavelength Magee AE22 Aethalometer & $\begin{array}{l}\text { Dalhousie University, } \\
\text { Gibson et al. (2013a) }\end{array}$ \\
\hline $\mathrm{PM}_{2.5}, \mathrm{PM}_{2.5-10}$ & $\begin{array}{l}\text { Teflon filter samples using Thermo Partisol } \\
2025 \text { dichotomous sampler; } \\
\text { filters analyzed for mass (gravimetric) } \\
\text { and elements (energy dispersive x-ray } \\
\text { fluorescence) }\end{array}$ & $\begin{array}{l}\text { Dalhousie University, } \\
\text { Gibson et al. (2009) }\end{array}$ \\
\hline $\begin{array}{l}\mathrm{PM}_{2.5} \text { anions and cations, } \\
\mathrm{PM}_{2.5} \text { organics, wood smoke } \\
\text { marks, and } \mathrm{OC} / \text { Elemental C }\end{array}$ & $\begin{array}{l}\text { Nylon filter samples using Thermo ChemComb } \\
\text { with integrated denuder to prevent } \\
\text { positive sulfate artifacts; } \\
\text { nylon filters analyzed by ion } \\
\text { chromotograph }\end{array}$ & $\begin{array}{l}\text { Dalhousie University, } \\
\text { Gibson et al. (2013a) }\end{array}$ \\
\hline $\begin{array}{l}\text { Total columns of } \mathrm{CO}, \mathrm{CH}_{4} \\
\mathrm{O}_{3} \text {, and } \mathrm{N}_{2} \mathrm{O}\end{array}$ & $\begin{array}{l}\text { Portable Atmospheric Research Interferometric } \\
\text { Spectrometer for the Infrared (PARIS-IR) } \\
\text { measuring solar absorption spectra } \\
\text { in the mid-IR }\left(750-4400 \mathrm{~cm}^{-1}\right) \\
\text { at a resolution of } 0.02 \mathrm{~cm}^{-1}\end{array}$ & $\begin{array}{l}\text { University of Toronto, } \\
\text { Fu et al. (2007) }\end{array}$ \\
\hline $\begin{array}{l}\text { Aerosol number concentrations } \\
(20-500 \mathrm{~nm} \text {, over } 6 \text { channels })\end{array}$ & $\begin{array}{l}\text { TSI } 3031 \text { Ultrafine Particle (UFP) Monitor } \\
(20-30 \mathrm{~nm}, 30-50 \mathrm{~nm}, 50-70 \mathrm{~nm}, 70-100 \mathrm{~nm} \text {, } \\
100-200 \mathrm{~nm}, 200-500 \mathrm{~nm})\end{array}$ & Environment Canada \\
\hline $\begin{array}{l}\text { Aerosol number concentrations } \\
(500 \mathrm{~nm}-20 \mu \mathrm{m} \text {, over } 52 \text { channels })\end{array}$ & TSI 3321 Aerodynamic Particle Sizer (APS) & Environment Canada \\
\hline $\begin{array}{l}\text { Aerosol ion characterization } \\
(10 \mathrm{~nm}-18 \mu \mathrm{m} \text {, over } 12 \text { size ranges })\end{array}$ & $\begin{array}{l}\text { MSP Micro-orifice Uniform Deposit Impactor } \\
\text { (MOUDI) 100/110NR for sulfate, nitrate, } \\
\text { sodium, chloride, ammonium, and pH }\end{array}$ & $\begin{array}{l}\text { Environment Canada, } \\
\text { Marple et al. (1991) }\end{array}$ \\
\hline $\begin{array}{l}\text { Aerosol speciation } \\
(40 \mathrm{~nm}-1 \mu \mathrm{m})\end{array}$ & $\begin{array}{l}\text { Aerodyne Aerosol Chemical Speciation Monitor } \\
\text { (ACSM) for ammonium, organics, sulfate, nitrate, chloride }\end{array}$ & $\begin{array}{l}\text { Environment Canada, } \\
\mathrm{Ng} \text { et al. (2011) }\end{array}$ \\
\hline $\mathrm{O}_{3}$ & $\begin{array}{l}\text { UV photometric analyzer } \\
\text { Thermo Scientific } 49 \mathrm{i}\end{array}$ & Environment Canada \\
\hline Aerosol optical thickness & $\begin{array}{l}\text { AERONET Sun Photometer } \\
(340,380,440,500,675,870,1020,1640 \mathrm{~nm})\end{array}$ & $\begin{array}{l}\text { Dalhousie University, } \\
\text { Holben et al. (1998) }\end{array}$ \\
\hline Aerosol optical thickness & $\begin{array}{l}\text { Star photometer } \\
(418.3,449.4,469.2,500.1,532.4,551.3,607.6 \text {, } \\
641.9,679.0,755.1,783.3,868.0,939.9,950.3, \\
959.9,1033.8 \text { and } 1048.5 \mathrm{~nm}) \\
\text { precision accuracy } 0.003<\Delta \tau<0.011\end{array}$ & $\begin{array}{l}\text { U. Sherbrooke, } \\
\text { Leiterer et al. (1995) }\end{array}$ \\
\hline
\end{tabular}


Table 5. Chemical and physical atmospheric observations at the Pico Mountain Atmospheric Research Observatory during BORTAS phases $\mathrm{A}$ and $\mathrm{B}$.

\begin{tabular}{ll}
\hline Measurement & Method/instrumentation \\
\hline Meteorological variables & $\begin{array}{l}\text { Commercial sensors for temperature, } \\
\text { relative humidity, wind speed and direction }\end{array}$ \\
\hline $\mathrm{O}_{3}$ & UV absorption, Thermoenvironmental Corp. Model 49C \\
\hline $\mathrm{CO}$ & NDIR, Thermo Environmental, Inc., Model 48C-TL \\
\hline $\mathrm{NO}, \mathrm{NO}_{2}, \mathrm{NO}_{\mathrm{y}}{ }^{*}$ & Custom-built chemiluminescence instrument \\
\hline $\mathrm{NMHCs}$ & $\begin{array}{l}\text { Custom-built preconcentration system with GC-FID } \\
\text { (Gas Chromatography with Flame Ionization Detector) }\end{array}$ \\
\hline $\mathrm{Black}$ carbon & Aethalometer, Magee Scientific Model AE31 \\
\hline Particle size & Intracavity Optical Particle Sizer/PMS LAS-X \\
\hline $\mathrm{CH}_{4}, \mathrm{~N}_{2} \mathrm{O}, \mathrm{SF}_{6},{\mathrm{CO}, \mathrm{CO}_{2},}_{\mathrm{NMHC}, \mathrm{CO}_{2} \text { and } \mathrm{CH}}$ stable isotopes & $\begin{array}{l}\text { Whole air sample collection into glass flask } \\
\text { samples with subsequent analysis at NOAA-GMD, USA }\end{array}$ \\
\hline
\end{tabular}

* Not available in 2011.
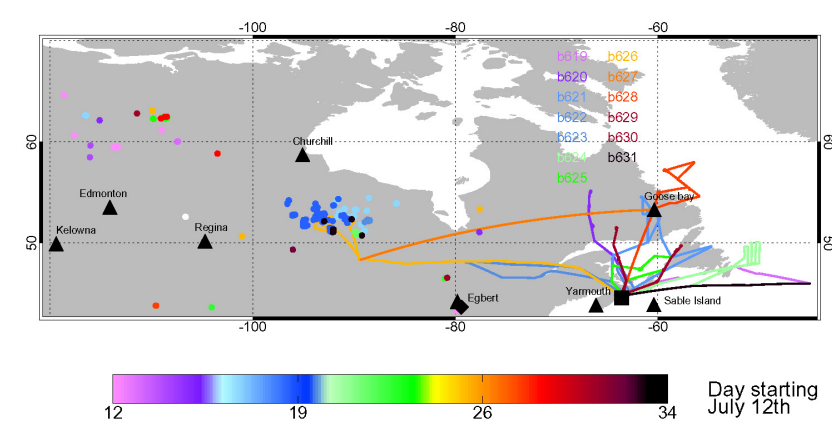

Fig. 6. Flight tracks for BORTAS, excluding inbound/outbound transit flights. Solid upward triangles denote ozonesonde launch sites, and the solid square denotes the Dalhousie ground station. The colour circles denote active burning throughout the BORTAS period. The flights and burning areas use a common colour scale that denotes the day number starting on 12 July 2011.

aircraft to larger spatial scales and longer temporal scales. During the campaign near-real-time satellite data were used to inform deployment of the BAe-146 aircraft. We used data from the Michelson Interferometer for Passive Atmospheric Sounding (MIPAS), the Atmospheric Chemistry Experiment (ACE), the Infrared Atmospheric Sounding Interferometer (IASI), and the Tropospheric Emission Spectrometer (TES).

We used near-real-time measurements from MIPAS (Fischer et al., 2008) aboard the Envisat satellite and IASI (Clerbaux et al., 2009) aboard the MetOp satellite to help us intercept pyrogenic plumes with the aircraft during BORTAS-B. MIPAS measures atmospheric limb emission spectra 14.5$4.1 \mu \mathrm{m}$ at a spectral resolution of $0.0625 \mathrm{~cm}^{-1}$ since January 2005 over a tangent altitude range $6-68 \mathrm{~km}$, and is in a polar sun-synchronous orbit with a local solar time of 10:00 and a 35-day repeat cycle. MIPAS observations were specially planned to coincide with BORTAS-B flights. IASI uses an infrared Fourier transform (FTIR) spectrometer to measure spectra $15.5-3.62 \mu \mathrm{m}$ at a spectral resolution of $0.5 \mathrm{~cm}^{-1}$, and is in a polar sun-synchronous orbit with a local solar time of 09:30 and a 29-day repeat cycle.

We also used data from ACE (Bernath et al., 2005; Tereszchuk et al., 2011, 2013), which is a high-resolution FTIR spectrometer that measures spectra 750 to $4400 \mathrm{~cm}^{-1}$ with a resolution of $0.02 \mathrm{~cm}^{-1}$. ACE aboard SCISAT-1, which is in a $74^{\circ}$ inclination circular orbit, can measure up to 30 sunrise and sunset occultations per day with a vertical resolution of $2-3 \mathrm{~km}$ from $150-5 \mathrm{~km}$ in cloud-free scenes. A number of trace gases are retrieved from the ACE spectra that are elevated in wildfires, e.g. $\mathrm{CO}$, acetonitrile, formic acid, formaldehyde, acetylene, ethane, and methanol (Tereszchuk et al., 2011, 2012).

In collaboration with colleagues at the NASA Jet Propulsion Laboratory, we requested special "step-and-stare" observations from TES (Beer et al., 2001) aboard the Aura spacecraft with a repeat cycle of 16 days. TES is a highresolution imaging FTIR spectrometer that observes spectral radiance in the range $650-3050 \mathrm{~cm}^{-1}$ at a resolution of $0.1 \mathrm{~cm}^{-1}$. It has an instrument field-of-view at the surface of $8 \mathrm{~km} \times 5 \mathrm{~km}$. Data from this instrument has been used previously to study boreal wildfires over Sibera (Verma et al., 2009) and Canada (Alvarado et al., 2010). The BORTAS-B step-and-stare TES observations effectively increased the spatial density of measurements over eastern Canada during BORTAS-B and subsequently increased the number of coincident profile measurements. 


\subsection{Model and data forecast products}

The main forecasting products for BORTAS-B included (1) NASA GEOS-5 (Global Earth Observing System) forecasts of carbon monoxide emitted by boreal biomass burning (latitudes $>50^{\circ}$ ), in collaboration with the Global Modeling and Assimilation Office at NASA Goddard; and (2) Environment Canada meteorological forecasts together with operational output from the air quality model GEM-MACH (Global Environmental Multi-scale-Modelling Air quality and CHemistry). We also used forecasts from the UK Meteorological Office and the European Centre for Medium-range Weather Forecasts, and used the HYbrid Single-Particle Lagrangian Integrated Trajectory (HYSPLIT) model (Draxler, 1999) to locate the origin of plumes observed by the aircraft.

As part of the deployment planning, we used nearreal-time fire data from: (1) Natural Resources Canada http://cwfis.cfs.nrcan.gc.ca/en_CA/fwmaps/fdr; (2) emission data from the Fire Locating And Monitoring of Burning Emissions (FLAMBE), which incorporates fire data from geostationary and polar-orbiting satellites (Reid et al., 2009); and (3) fire products from the NASA ModerateResolution Imaging Spectroradiometer (MODIS) instruments from the Fire Information for Resource Management System (FIRMS) via the NASA Earth Observing System Data and Information Service. This information is independent of the Quick Fire Emission Dataset (QFED) developed by NASA and used by the GEOS- 5 CO forecasts (Rienecker et al., 2008; Ott et al., 2011). CO total column and profile data from IASI (described above), available $<3 \mathrm{~h}$ after measurements, was also used for plume tracking and flight planning during BORTAS.

\section{First results and science overview}

The BORTAS-B airborne campaign delivered a rich dataset to better understand chemistry in biomass burning plumes, partly serendipitously because of the timing and location of fires over Northwestern Ontario during our Halifax-based deployment (Fig. 6). Here, we briefly describe analysed results and refer the reader to dedicated papers. We discuss ongoing work and future perspectives in Sect. 5.

\subsection{Intercepting pyrogenic plumes}

Intercepting pyrogenic plumes is non-trivial, but we found that GEOS-5 CO fields reliably forecasted the general spatial distribution of the plumes, allowing us to accordingly deploy the BAe-146. Figure 7 shows the GEOS-5 CO forecast for B624 on 21 July 2011, which showed pyrogenic plumes in the mid-lower troposphere over Newfoundland Island and the Gulf of St. Lawrence. The flight pattern was designed to maximize time within the plume and explore the vertical dimension. These aircraft observations serve to illustrate the rapid horizontal and vertical gradients associated
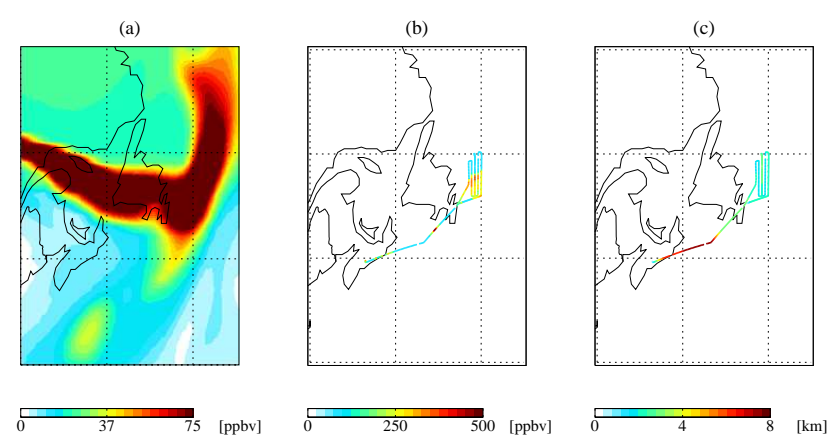

Fig. 7. (a) GEOS-5 model CO concentration (ppb) forecast for $1930 \mathrm{Z}$ at $750 \mathrm{hPa}$ (initialized at $00 \mathrm{Z}$ on the same day), (b) BAe146 aircraft $\mathrm{CO}$ measurements $(\mathrm{ppb})$ and $(\mathbf{c})$ altitude $(\mathrm{km})$ for flight B624, 21 July 2011.

with the plume. Figure 8 shows that these plumes indeed travel as thin, coherent filaments with a vertical dimension of the order of $100 \mathrm{~m}$, in agreement with previous studies, reflecting possibly vertical wind shear where the material was first lofted into the atmosphere or buoyancy-driven spreading after an air mass reaches its level of neutral buoyancy (Hogg et al., 2013). During flights, guided by forecast products (described above), we identified plumes primarily by elevated $\mathrm{CO}$ concentrations but also changes in uncalibrated mass to charge $(\mathrm{m} / \mathrm{z})$ counts associated with $\mathrm{CH}_{3} \mathrm{CN}$ from the PTR-MS. Once we intercepted a plume, based on the chemical criteria, we typically focused on constant altitude runs within the plume, with limited vertical and horizontal sampling to explore the plume dimension and the associated chemical gradients. As part of BORTAS we parameterized time-dependent forecast skill of the GEOS-5 CO fields using optical flow methods (Keil and Craig, 2009), which is the subject of an upcoming paper (Matthiesen et al., 2013). Associated with these filamental structures were rapid gradients in $\mathrm{O}_{3}$ across the plume boundaries, in agreement with previous studies of near-field power plant plumes that showed a non-linear response to levels of $\mathrm{NO}_{\mathrm{x}}$ (Ryerson et al., 2001).

For BORTAS scientific studies we have chosen to use CO, together with biomass burning tracers acetonitrile $\left(\mathrm{CH}_{3} \mathrm{CN}\right)$ and hydrogen cyanide $(\mathrm{HCN})$, to identify biomass-burning plumes. By virtue of the primary scientific objective of BORTAS, the resulting airborne data are biased to biomass burning plumes so that we cannot use the mean statistics of these data to identify plumes, an approach adopted by other campaigns. Instead, we have used measurements from a single flight (B625, 24 July 2011, Fig. 6) during which we sampled almost exclusively concentrations representative of the background atmosphere; mean and median values were lower than those derived from all the data, and there was no significant statistical relationship between $\mathrm{CO}$ and $\mathrm{CH}_{3} \mathrm{CN}$. Even in the background atmosphere, we expect a distribution of trace gas concentrations. Here, we define a plume that has a value greater than the 99 th percentile $(\simeq$ mean \pm 3 


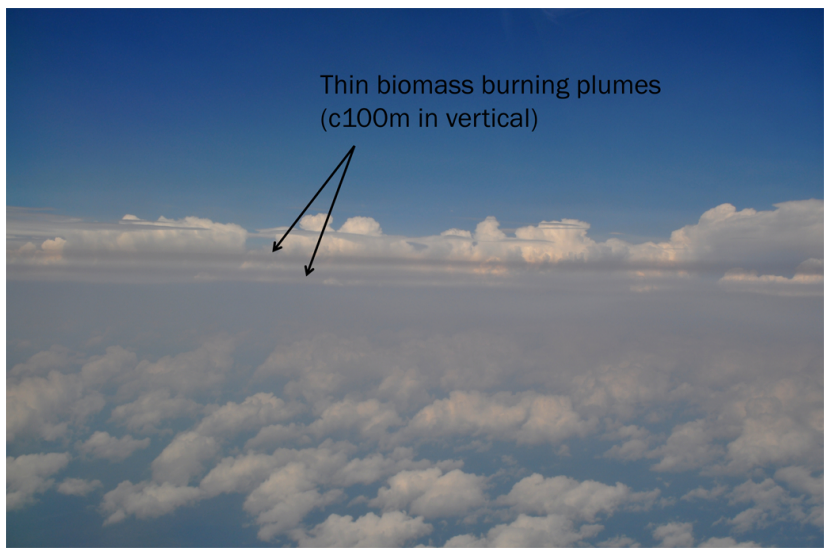

Fig. 8. A photograph (c/o Steve Andrews) from the BAe-146 at ca. $7 \mathrm{~km}$ altitude during BORTAS-B (flight B624, 21 July 2011) illustrating the thin filaments of pyrogenic outflow.

standard deviations) of the $\mathrm{B} 625$ data. For $\mathrm{CO}, \mathrm{CH}_{3} \mathrm{CN}$, and $\mathrm{HCN}$ these 99th percentile threshold values are $148 \mathrm{ppb}$ $(n=237), 150 \mathrm{ppt}(n=236)$, and $122 \mathrm{ppt}(n=118)$, respectively. These stringent constraints necessarily remove a substantial amount of data that varies with the tracer: $85 \%$ for $\mathrm{CO}$ and $60 \%$ for $\mathrm{HCN}$ and $\mathrm{CH}_{3} \mathrm{CN}$. This admittedly crude statistical analysis helps to justify our method of plume identification and provides a definition for all subsequent BORTAS scientific studies. Most scientific studies have used the $\mathrm{HCN}$ and $\mathrm{CH}_{3} \mathrm{CN}$ criteria to retain data.

Figure 9 shows significant contributions of total $\mathrm{CO}$ from biomass burning regions during the BORTAS-B period, as depicted by the tagged version of the GEOS-Chem global 3-D model (Parrington et al., 2012). The model is driven by uncorrected FLAMBE biomass burning emission estimates, which are known to have a positive bias. At the surface over eastern Canada, where BORTAS-B took place, the largest contribution to $\mathrm{CO}$ is from Siberia (as it is indeed for the rest of the Northern Hemisphere), with substantial contributions from Eastern and Western Canada and the Southwestern and Eastern United States. In the free troposphere, where the aircraft spent most of its time, the background is dominated by Siberian burning with near-field variations also from Eastern and Western Canada. Particularly strong Siberian burning episodes were observed on 28 July using IASI CO data, although enhanced $\mathrm{CO}$ amounts were detected over this region throughout the BORTAS-B period. A more detailed treatment of the emission and transport of biomass burning emission will the subject of ongoing work.

\subsection{Emission ratios for organic compounds}

Direct emissions from open biomass burning (i.e. incomplete combustion) are largely composed of $\mathrm{CO}_{2}$ and $\mathrm{H}_{2} \mathrm{O}$ but also include $\mathrm{CO}$ and a suite of organic compounds. The relative abundance of these organic species depends on the phase of
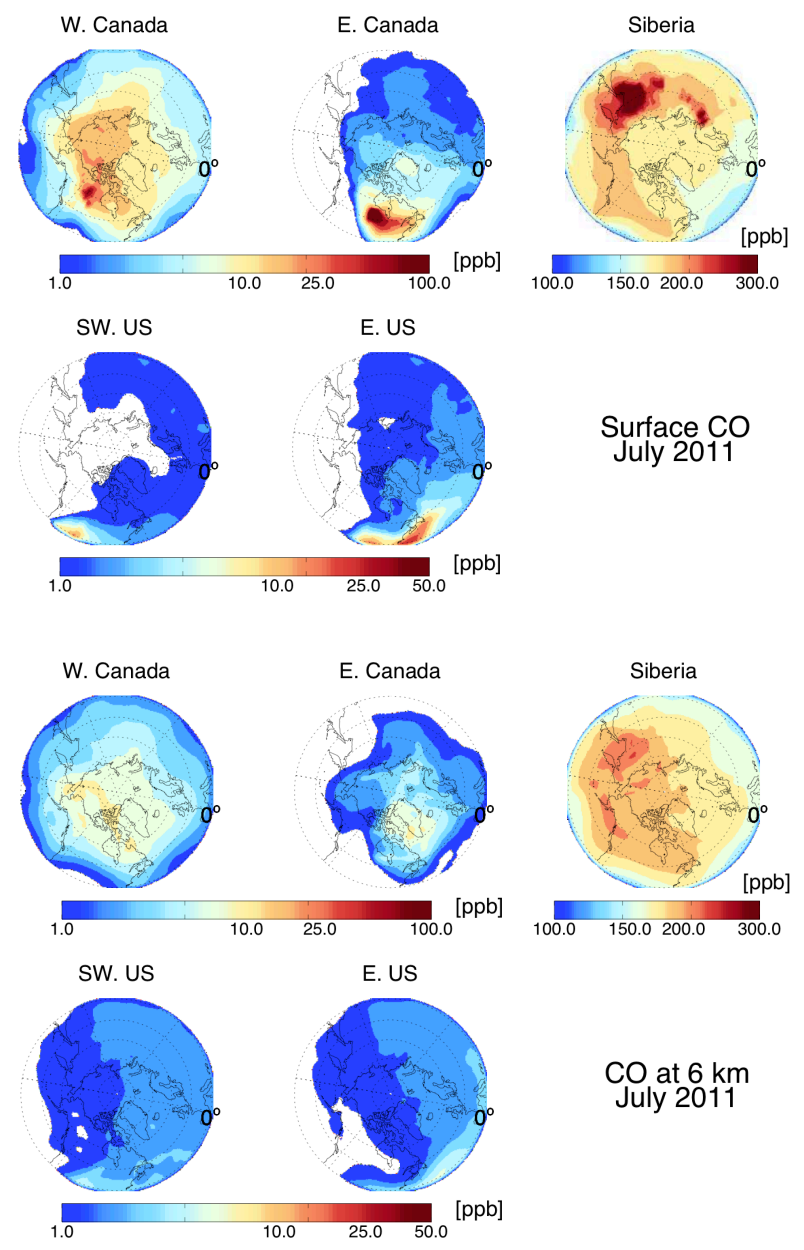

Fig. 9. Monthly mean GEOS-Chem global 3-D chemistry model output for July 2011 that describes pyrogenic contributions to total CO (ppb) from Western Canada, Eastern Canada, Siberia, southwestern contiguous US and eastern contiguous US. The upper (lower) panel shows CO concentration at the surface $(6 \mathrm{~km})$.

the fire (flaming or smouldering). The co-emission of these organic compounds along with $\mathrm{CO}$ has been reported extensively, and the correlation of these with $\mathrm{CO}$ and with dry mass of biomass burnt has been used to derive emission ratios (ERs) and emission factors (EFs) (see for example (Andreae and Merlet, 2001)). During BORTAS-B we determined a wide range of emission ratios for organic compounds (expressed as ppt[NMHC] per ppb[CO]) using data from whole air samples analysed on the ground using GC-FID and inflight for selected species using PTR-MS. Derived ER values during BORTAS-B (Lewis et al., 2013) agreed very well for many species with earlier experiments over a similar geographic region (Simpson et al., 2011), providing confidence in subsequent analysis involving the scaling-up of these measurements using $\mathrm{CO}$ fire emission estimates and a global 3-D chemistry transport model. In particular, the BORTAS-B ERs 
have been used to determine the extent to which biomass burning contributes to the global distribution of species such as benzene, ethene, propene and toluene, which are traditionally thought of as mainly anthropogenic tracers whose regulation has seen a continued decline in developed countries. Analysis using the GEOS-Chem chemistry transport model shows that in many remote locations biomass burning can be the dominant hydrocarbon source (Lewis et al., 2013).

There is widespread evidence of pyrogenic emission of many simple non-methane hydrocarbons (NMHCs) and small oxygenated compounds such as methanol and acetone, but emission of larger polar and semi-volatile species are less well characterized. These species have lower vapour pressures than simple non-methane hydrocarbons, so that if they are transported under cool free-troposphere conditions they can partition into the aerosol phase. Laboratory studies (e.g. Christian et al., 2004) and near-field measurements (e.g. Yokelson et al., 2008) of forest burning biomass show that a range of higher carbonyl compounds are released, and there is some evidence of enhanced emissions of monoterpenes and longer chain aliphatic compounds. However, detection of these compounds in the field, and in particular in plumes undergoing long-range transport, is analytically difficult. They are often not amenable to sampling and storage in whole air sampling canisters because of wall and $\mathrm{O}_{3}$ losses, and the complexity of isomers makes PTR-MS an unsuitable technique for individual speciation. BORTAS-B provided the first flight opportunities for a fast response in-flight GC-MS designed specifically for $\mathrm{C}_{5}-\mathrm{C}_{12}$ VOCs including oxygenated compounds and monoterpenes. Intercepted boreal biomass burning plumes in the mid-troposphere showed that species such as furfural, benzaldehyde, benzonitrile, acetophenone and benzoic acid were present in significant abundances, and that downwind fire plumes also showed elevated higher hydrocarbons such as naphthalene and monoterpenes, including alpha pinene, camphene, beta-pinene, 3-carene limonene and eucalyptol. ERs for these species from aged plumes have been determined, and their phase partitioning estimated for a range of plume temperatures. The addition of an in-flight GC-MS to BORTAS-B also provided additional discrimination to PTR-MS data, in particular providing a quantitative measurement of the relative abundance of furan and isoprene species that give a combined response by PTR-MS, and which vary greatly as forest-influenced air masses from burnt and unburnt regions are encountered. These data are reported in greater detail by Purvis et al. (2013).

\subsection{Ozone photochemistry in pyrogenic plumes}

Ozone photochemistry in boreal biomass burning plumes was evaluated using measurements of $\mathrm{NMHCs}$ and $\mathrm{NO}_{\mathrm{y}}$ species made from the BAe-146 with different instruments. The observed $\mathrm{O}_{3}$ distribution in pyrogenic outflow, identified using tracers such as $\mathrm{CO}$ and $\mathrm{CH}_{3} \mathrm{CN}$, during the campaign showed no distinguishable difference to the ob- served distribution in clean air. At the highest values of $\mathrm{CO}(>300 \mathrm{ppb}), \mathrm{O}_{3}$ mixing ratios were observed in a relatively narrow range between approximately 40 and $60 \mathrm{ppb}$. Parrington et al. (2013) show that the enhancement ratio $\Delta \mathrm{O}_{3} / \Delta \mathrm{CO}$, crudely characterizing $\mathrm{O}_{3}$ production, is generally positive and increases with photochemical age (described below) from $0.020 \pm 0.009 \mathrm{ppbv} \mathrm{ppbv}^{-1}$ at ages less that 2 days to $0.75 \pm 0.41 \mathrm{ppbv} \mathrm{ppbv}^{-1}$ for ages greater than 5 days. The increase in ratio is due largely to an increase in $\Delta \mathrm{O}_{3}$ rather than the smaller decrease in $\Delta \mathrm{CO}$ with age.

Photochemical processes influencing the $\mathrm{O}_{3}$ distribution in boreal biomass burning plumes were evaluated through (1) photochemical age calculations, using ratios of different alkanes assuming a common sink of oxidation by $\mathrm{OH}$ (Parrish et al., 2007); and (2) comparison of the observed $\mathrm{O}_{3}$ distribution relative to total alkyl nitrates and the surrogate species $\mathrm{NO}_{\mathrm{z}}\left(=\mathrm{NO}_{\mathrm{y}}\right.$ minus $\mathrm{NO}_{\mathrm{x}}$, the sum of $\mathrm{NO}_{\mathrm{x}}$ oxidation products) (Olszyna et al., 1994; Rickard et al., 2002), representing the conversion of $\mathrm{NO}_{\mathrm{x}}$ into $\mathrm{O}_{3}$ (Parrington et al., 2013). Photochemical ages, calculated relative to initial mixing ratios derived from research flight B626 over Northwestern Ontario, produced values of between 2-3 days aging for the strongest plumes $(\mathrm{CO}>300 \mathrm{ppb})$ encountered in the lower troposphere earlier in the campaign (i.e. flights B622-B624) and > 5 days for plume air that was encountered at higher altitudes later in the campaign (i.e. flights B628-B630); Table 6 reports the range of photochemical ages of pyrogenic plumes for each flight. Graphical comparison of the $\mathrm{O}_{3}$ distribution to that of the alkyl nitrates and $\mathrm{NO}_{\mathrm{z}}$ revealed clear "L-shape" patterns (not shown) with higher values of alkyl nitrates/ $\mathrm{NO}_{\mathrm{z}}$ at lower values of $\mathrm{O}_{3}$, and lower values of alkyl nitrates $/ \mathrm{NO}_{z}$ at higher $\mathrm{O}_{3}$. The two branches of these "L-shape" patterns revealed a clear distinction between measurements with different characteristics: (1) high measurements of alkyl nitrates/ $\mathrm{NO}_{\mathrm{z}}$ and lower $\mathrm{O}_{3}$ were typically made at lower altitudes (below $5 \mathrm{~km}$ ), with higher values of black carbon mass concentration $\left(>0.1 \mu \mathrm{g} \mathrm{cm}^{-3}\right)$ and at higher relative humidity (greater than $80 \%$ ); and (2) low alkyl nitrates $/ \mathrm{NO}_{z}$ and high $\mathrm{O}_{3}$ measurements were typically made at higher altitudes, with lower black carbon mass concentration $\left(<0.1 \mu \mathrm{g} \mathrm{cm}^{-3}\right)$, and low relative humidity $(<$ $80 \%$ ). Further comparison of the $\mathrm{O}_{3}$ production efficiency, calculated from the ratio of $\mathrm{O}_{3}: \mathrm{NO}_{\mathrm{z}}$, to measured $\mathrm{NO}_{\mathrm{x}}$ mixing ratios indicated that BORTAS measurements were made under different chemical regimes. Lower values of $\mathrm{O}_{3}$ production efficiency (less that $150 \mathrm{ppb} \mathrm{O}_{3} \mathrm{ppb}^{-1} \mathrm{NO}_{\mathrm{z}}$ ) show a larger range of $\mathrm{NO}_{\mathrm{x}}$ mixing ratios $(0.05-1.0 \mathrm{ppb})$, indicative of a VOC-limited regime, and higher values (greater than $150 \mathrm{ppb} \mathrm{O}_{3} \mathrm{ppb}^{-1} \mathrm{NO}_{\mathrm{z}}$ ) show a narrower range of $\mathrm{NO}_{\mathrm{x}}$ mixing ratios (0.0-0.2 ppb), indicative of a $\mathrm{NO}_{\mathrm{x}}$-limited regime. This work is reported by Parrington et al. (2013). 

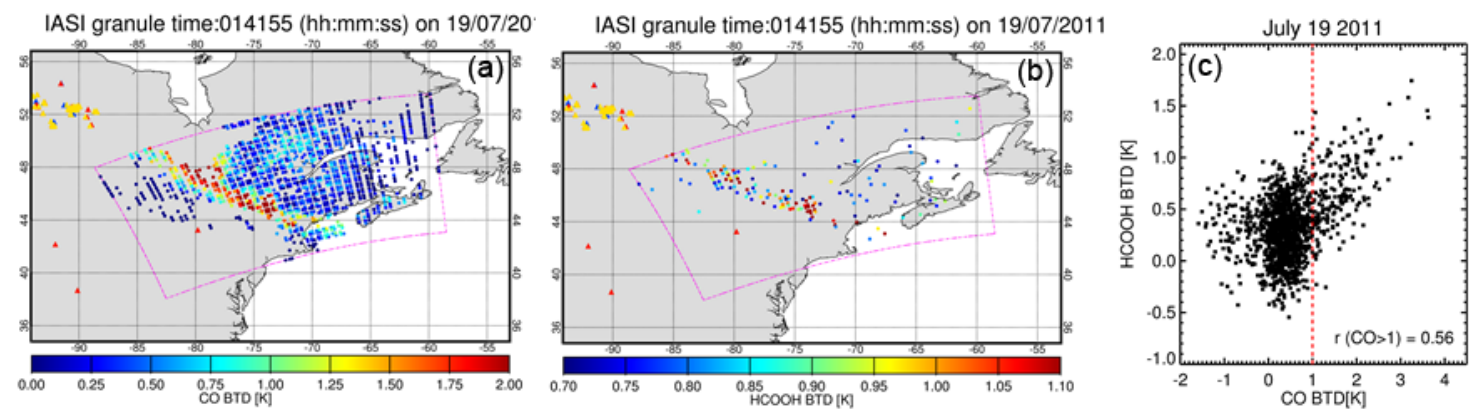

Fig. 10. Brightness temperature difference (BTD, K) detection of (a) $\mathrm{CO}$ and (b) formic acid (HCOOH) enhancements from a single IASI data granule for 19 July 2011. MODIS fire count data are shown as triangles according to detection certainty: high (red), nominal (yellow), and low (blue) confidence. (c) The corresponding scatter plot of $\mathrm{CO}$ and $\mathrm{HCOOH}$ with the Pearson correlation coefficient $r$ shown inset.

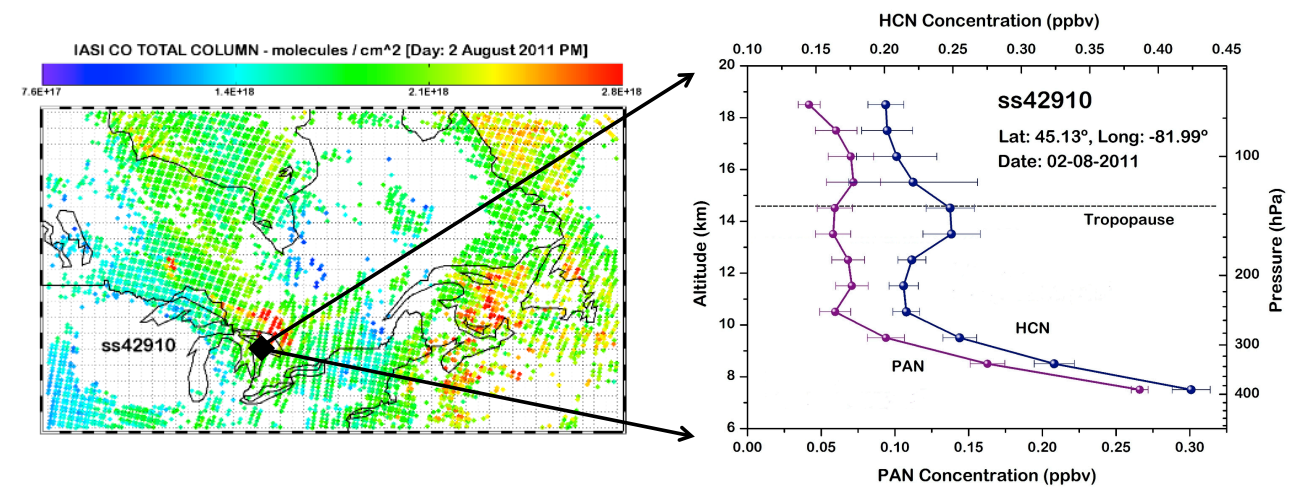

Fig. 11. Left: IASI total column CO (molec $\mathrm{cm}^{-2}$ ) for 2 August 2011. The black diamond superimposed denotes the position of occultation ss42910 from the ACE space-borne sensor. Right: vertical profiles of HCN (ppb) and PAN (ppb) from ACE during occultation ss42910 $\left(45.13^{\circ} \mathrm{N},-81.99^{\circ} \mathrm{W}\right)$.

Table 6. Range of photochemical ages of air masses, identified as being of pyrogenic origin using $\mathrm{CO}, \mathrm{CH}_{3} \mathrm{CN}$ and $\mathrm{HCN}$ concentrations, intercepted during non-transit BORTAS-B flights, 15 July-31 July 2011.

\begin{tabular}{ll}
\hline Flight \# & Photochemical age (days) \\
\hline B620 & - \\
B621 & Typically 3-4, few older \\
B622 & Typically 1-5, few younger and older \\
B623 & Typically 2-4, few older \\
B624 & Typically 2-4, few younger and older \\
B625 & - \\
B626 & $\geq$ 5 earlier in flight, 1-2 later in flight \\
B627 & - \\
B628 & Typically 8-11 \\
B629 & Typically 5-8 \\
B630 & Typically 5-9 \\
\hline
\end{tabular}

\subsection{Using data to test chemical mechanisms}

Describing the observed photochemistry using a hierarchy of chemical mechanisms, a core objective of BORTAS, allows us to investigate the uncertainties in our understanding of $\mathrm{O}_{3}$ production and loss within the biomass burning outflow and to quantify the resulting perturbation to tropospheric chemistry over the western boundary of the North Atlantic. Here, we used v3.2 of the Master Chemical Mechanism (MCM; http://mcm.leeds.ac.uk/MCM), a near-explicit chemical mechanism describing the detailed gas-phase degradation of a series of primary emitted VOCs (Saunders et al., 2003), which contains 143 primary emitted VOCs and 6700 species involved in 17000 reactions. We also used a reduced chemical mechanism, the "common representative intermediates" (CRIv2 mechanism) (Jenkin et al., 2008), which is benchmarked against the more comprehensive MCM. The CRI mechanism provides an economical alternative to the MCM that can be applied to global 3-D CTMs such as GEOS-Chem whilst retaining much of the fidelity of the more detailed mechanism. The CRI mechanism contains a series of generic intermediate radicals and products (based 
on the $\mathrm{O}_{3}$ creation potential for a given VOC), each of which is able to represent a larger set of species in the MCM. These generic intermediates mediate the breakdown of larger VOCs into smaller fragments, the chemistry of which is treated explicitly. The latest version of the CRI mechanism (v2) contains 442 species and 1191 reactions (7\% of the full MCM). These mechanisms will be compared against the GEOS-Chem mechanism that is much less detailed than the CRI mechanism. We have used photochemical models, incorporating MCMv3.2 and CRIv2 mechanisms, and constrained them with BORTAS aircraft observations to (1) investigate the chemistry controlling $\mathrm{O}_{3}$ formation and loss and $\mathrm{NO}_{\mathrm{y}}$ speciation along each BORTAS flight track, (2) evaluate the CRI mechanism, and subsequent reduced versions (following Watson et al., 2008), and the GEOS-Chem mechanism against the benchmark MCM, and (3) evaluate the initialization and speciation methodologies applied during the bottom-up model studies (Hays et al., 2002; Simpson et al., 2011). We find that the CRI mechanism typically reproduces oxidant concentrations from the benchmark MCM calculations over 5-10 days, with most of the photochemical $\mathrm{O}_{3}$ formed within the first $12-15 \mathrm{~h}$ of daylight after emission, and captures most of the variation in the aircraft observations. This work is described by Young et al. (2013).

\subsection{Observing pyrogenic plumes from space}

We used MIPAS products (described in Sect. 3.4) developed by the University of Leicester, including CO, PAN, acetylene, formic acid, ethane, and acetone (Moore and Remedios, 2010; Parker et al., 2010; Moore et al., 2012; Illingworth et al., 2011), which have been shown previously to be markers of wildfires (Alvarado et al., 2010). The IASI near-real-time $\mathrm{CO}$ data product was provided by C. Clerbaux (CNRS/INSU, LATMOS-IPSL, Paris, France) and P.-F. Coheur (Université Libre de Bruxelles, Brussels, Belgium) (Clerbaux et al., 2009; George et al., 2009). We also used IASI products developed by the University of Leicester, including $\mathrm{CO}$, formic acid, and acetylene, with detection products for these compounds and also ethene, ammonia, and HCN. Figure 10 shows an example of how these detection products were used in BORTAS-B to understand the spatial extent of biomass burning plumes. The data show a distinct CO plume over eastern Canada on 19 July 2011, derived from the difference in brightness temperature between $5 \mu \mathrm{m}$ and $10 \mu \mathrm{m}$, which also corresponds to elevated concentrations of formic acid. Figure 11 shows IASI total column CO for 2 August 2011, with a black symbol superimposed denoting the location of an ACE occultation profile from which we show a profile of $\mathrm{HCN}$ and PAN down to $7 \mathrm{~km}$. Both PAN and HCN show elevated concentrations suggesting this enhancement is due to the biomass burning outflow shown by IASI.

Figure 12 shows a comparison between an $\mathrm{O}_{3}$ profile measured from the BAe-146 during its descent into Thunder Bay
Airport, Ontario, on 26 July 2011 and a colocated $\mathrm{O}_{3}$ profile retrieved by TES on the same date separated by approximately $30 \mathrm{~km}$ and $4 \mathrm{~h}$. Figure 12a shows the raw $1 \mathrm{~s}$ aircraft $\mathrm{O}_{3}$ measurement, the TES retrieval and its prior, and the aircraft profile smoothed by the TES averaging kernels. The prior for the TES $\mathrm{O}_{3}$ retrieval has been scaled to the aircraft profile, and the retrieved $\mathrm{O}_{3}$ profile has been adjusted to this scaled prior, following Kulawik et al. (2008) and Rodgers and Connor (2003). The aircraft profile was smoothed with the TES averaging kernels by (i) removing repeat measurements at the same vertical level, (ii) appending the scaled prior to extend it into the stratosphere, and (iii) interpolating it to the TES vertical pressure grid. Figure 12b shows the averaging kernels for the retrieved $\mathrm{O}_{3}$ profile. The $\mathrm{O}_{3}$ profile measured from the BAe-146 showed relatively low (20-40 ppb) mixing ratios between the surface and $750 \mathrm{hPa}$, with a relatively thick layer of enhanced $\mathrm{O}_{3}$ extending from 700 to $400 \mathrm{hPa}$ with mixing ratios of $50-80 \mathrm{ppb}$. The prior profile used in the TES retrieval was scaled to match the $\mathrm{O}_{3}$ mixing ratio measured from the aircraft at the highest pressure level (approximately $350 \mathrm{hPa}$ ). Between the surface and this pressure level, the scaled prior is representative of background tropospheric $\mathrm{O}_{3}$ mixing ratios (red dotted line in Fig. 12a). The TES $\mathrm{O}_{3}$ profile (red solid line in Fig. 12a) showed a similar vertical distribution to the aircraft profile with mixing ratios of $20-40 \mathrm{ppb}$ below $750 \mathrm{hPa}$, similar to the prior, increasing to approximately $60 \mathrm{ppb}$ at $400 \mathrm{hPa}$. The averaging kernels in Fig. $12 \mathrm{~b}$ indicate that this retrieval was not sensitive to $\mathrm{O}_{3}$ at the lowest pressure levels of the profile but was sensitive to the pressure levels with the observed $\mathrm{O}_{3}$ enhancement. At higher pressure levels (lower altitudes), the TES profile showed good agreement with the raw aircraft measurements. Comparison against the aircraft profile smoothed with the TES averaging kernels, however, indicated that the TES retrieval overestimated the $\mathrm{O}_{3}$ profile in the middle troposphere by up to $20 \mathrm{ppb}$. This simple-minded comparison serves to illustrate the challenges associated with extracting information from space-borne instruments about atmospheric processes that have vertical structures that are generally finer than the vertical resolution of the instruments without using more sophisticated analyses that account for instrument error characteristics.

\subsection{Source attribution of surface $\mathbf{P M}_{2.5}$}

Source attribution of observed variations in $\mathrm{PM}_{2.5}$ (Table 4) at the DGS was achieved using a combination of statistical data analysis of the measurements and atmospheric transport modelling. During the BORTAS-B period, 45 consecutive days of filter samples were collected at the DGS, the analysis from which was combined with continuous measurements of black carbon (BC) and organic carbon (OC) (Table 4).

Gibson et al. (2013a) use the US EPA Positive Matrix Factorization v3.0 (PMF) receptor model (Paatero and Trapper, 1994) to determine the source contribution of boreal forest 

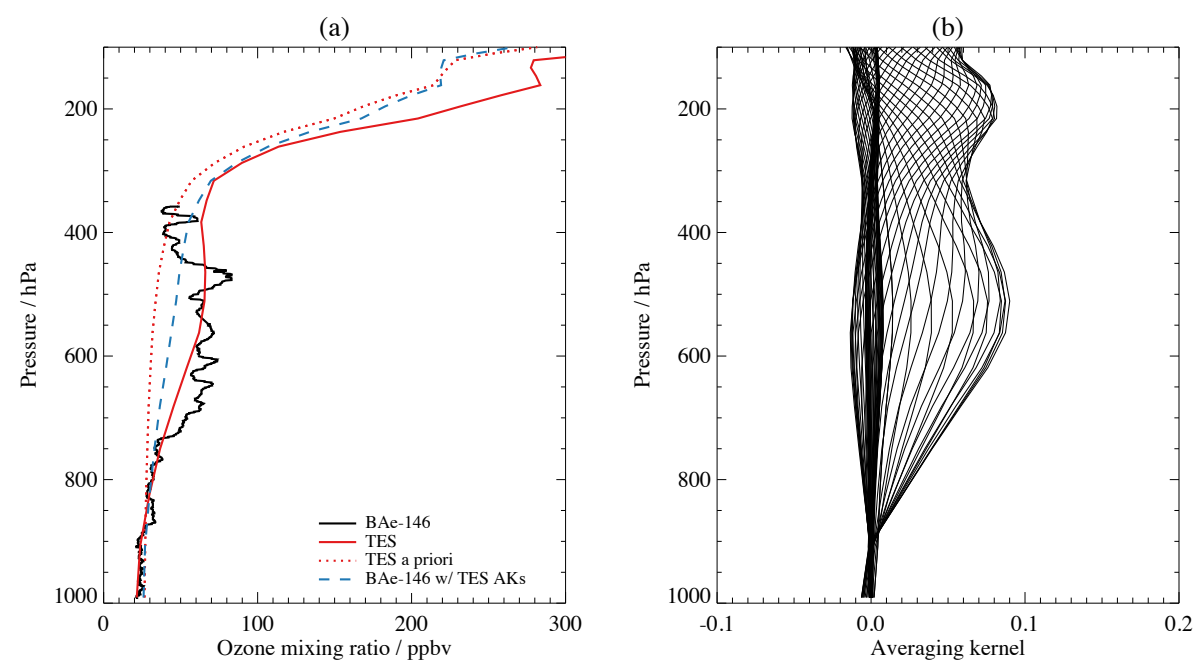

Fig. 12. Ozone profiles measured during a descent of the BAe-146 into Thunder Bay, ON, on 26 July 2011. Plot (a) shows the $\mathrm{O}_{3}$ profile measured from the BAe-146 (solid black line), retrieved from the collocated TES measurements and its prior (solid and dotted red lines, respectively), and the aircraft profile smoothed with the TES averaging kernels. Plot (b) shows the averaging kernels for the TES $\mathrm{O}_{3}$ profile retrieval.

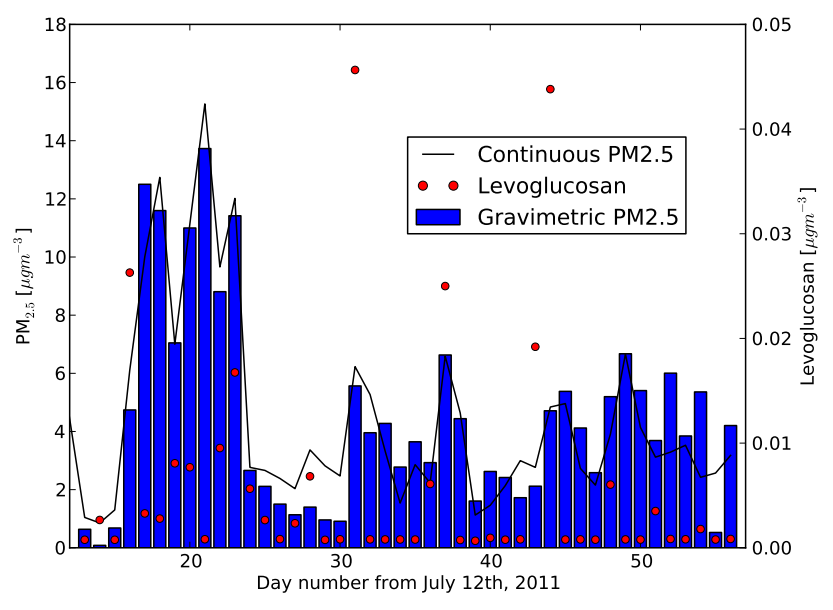

Fig. 13. Time series of $24 \mathrm{~h}$ average gravimetric and continuous $\mathrm{PM}_{2.5}\left(\mu \mathrm{g} \mathrm{m}^{-3}\right)$ and $24 \mathrm{~h}$ filter-based levoglucosan samples $(\mu \mathrm{g}$ $\mathrm{m}^{-3}$ ) from 12 July-25 August 2011, encompassing the BORTAS-B measurement period.

fire aerosol to the total surface $\mathrm{PM}_{2.5}$ mass concentration in Halifax (Song et al., 2001; Larson et al., 2004). The identification of the boreal forest fire source "factor" within PMF was characterized by the simultaneous increase in the chemical markers potassium and $\mathrm{BC}$ and corresponding decreases in other source markers, e.g. secondary ions, surficial material, sea salt, ship and vehicle emissions (Jeong et al., 2008; Ward et al., 2012). The identified boreal forest fire source "factor" was also found to be coincident with FLEXPART and HYSPLIT back trajectories from known boreal forest fire source regions and with corresponding elevated surface $\mathrm{CO}$ concentrations predicted using the GEOS-Chem model.
Measurements from the Raman LiDAR and from the BAe146 provided further evidence for boreal forest fire aerosol contributing to surface $\mathrm{PM}_{2.5}$ mass concentration in Halifax (Gibson et al., 2013a).

Figure 13 shows pre-fire quartz filter measurements of levoglucosan, a tracer for celluose in biomass burning (Simoneit et al., 1999); we acknowledge that some of the levoglucosan variability may be due to the $\mathrm{OH}$ sink (Hennigan et al., 2010). The increase in $\mathrm{PM}_{2.5}$ mass during days $16-23$ is due to a mixture of long-range secondary ions, organic carbon, marine aerosol and biomass burning (confirmed by the presence of levoglucosan). Using a back-trajectory model, we find that elevated levoglucosan mass on day 23 is related to a large wildfire in Northern Ontario. Elevated mass on days 16, 31, 37,43 , and 44 were also related to upwind boreal fires. The anomalous low $\mathrm{PM}_{2.5}$ values on days 13,14 and 15 were due to clean airflow from Northern Canada. This analysis is the subject of ongoing work (Gibson et al., 2013b).

\section{Concluding remarks}

The BORTAS-B experiment during 12 July-3 August 2011 has delivered a large, diverse, and publicly available dataset that brings together aircraft, ground-based, balloon, and space-borne data associated with the pyrogenic emission and subsequent transport and photochemical aging of associated air masses over Canada. The timing of the experiment reflects the climatological maximum of burning over this geographical region. Our choice to base the UK BAe-146-301 Atmospheric Research Aircraft at Halifax, Nova Scotia, was because this region was one of the climatological loci of burning outflow over eastern Canada. 
We have described the BORTAS experimental objectives and the methods and data we used to address them. We have also included brief descriptions of the Canadian ground station at Dalhousie University, which included a large suite of measurements to characterize the composition of pyrogenic material at ground level and to investigate trace gases and aerosols above the site, and the Pico Mountain Atmospheric Research Observatory in the Azores, located in the free troposphere days downwind of North American fires.

During the experiment, in order to help us determine our flight plans, we used a combination of GEOS-5 forecast 3-D fields of $\mathrm{CO}$, near-real-time measurements of $\mathrm{CO}$ from the IASI satellite, and a range of meteorological products from Environment Canada, ECMWF and the UK Meteorological Office. We found the GEOS-5 forecast fields were generally reliable (without using any quantitative metric) in helping us laterally intercept both near-field and far-field pyrogenic plumes. We found pyrogenic plumes travelled in vertical filaments of the order of $100 \mathrm{~m}$, even far downwind of any potential source.

The Northwestern Ontario fires, whilst devastating for local communities, provided BORTAS-B an unprecedented opportunity to sample near-field and far-field measurements from the same fires, allowing us to evaluate a variety of models based on our fundamental understanding of atmospheric photochemistry. The high-resolution/frequency measurements aboard the UK BAe-146 in particular provided a wealth of information about emissions, chemical aging of air masses (from a few days to over a week), and the subsequent transport of plumes.

A fast response in-flight GC-MS aboard the BAe-146, which avoids storage difficulties associated with sampling canisters, reported a large suite of gases including semivolatile species, some for the first time. The corresponding study reports the associated emission ratios, generally consistent with gases common to previous work, and phase partioning. Analysis of the aircraft data, particularly the reactive and reservoir nitrogen species, shows net ozone production in the plumes as they photochemically age, with production controlled by aerosol abundance. The enhancement ratio of $\Delta \mathrm{O}_{3} / \Delta \mathrm{CO}$ during BORTAS is generally positive and increases with age, largely determined by an increase in $\Delta \mathrm{O}_{3}$. These measurements join a growing body of evidence that biomass burning does produce substantial downwind $\mathrm{O}_{3}$ that can influence surface concentrations over North America and should therefore be included in any future changes in surface air quality regulations. The role of North American boreal forest fires on European surface $\mathrm{O}_{3}$ during BORTAS, involving transatlantic transport of plumes, is the subject of ongoing work. The Dalhousie Ground Station, based in Halifax, includes a range of in situ and remotely sensed instruments for characterizing surface air pollution and long-range transport in the free troposphere. Its role, together with available $\mathrm{O}_{3}$ sondes, was to relate the aircraft measurements, mainly focused on the free troposphere, to boundary layer concentra- tions of biomass burning pollutants. Surface measurements were collected before, after, and during the BORTAS-B aircraft campaign and showed episodic transport of biomass burning pollutants that reached the surface, identified primarily through elevated values of levoglucosan and through a positive matrix factorization contribution characterized by an increase in potassium, black carbon and corresponding decreases in other markers. Measurements from the Raman aerosol LiDAR provided further evidence of the vertical distribution and extent of forest fire aerosol over Halifax. Observations from the Pico Mountain Atmospheric Research Observatory in the Azores were available during BORTAS-B, but unlike recent previous years much of the boreal forest fire pollutants travelled across the North Atlantic at higher latitudes. Space-borne observations of land surface properties and trace gases associated with biomass burning helped us to deploy the aircraft during BORTAS-B and have subsequently helped to relate qualitatively aircraft measurements taken during BORTAS-B to the larger spatial scales and longer temporal scales. Whenever possible during the campaign, we coordinated the aircraft to provide coincident profile measurements with the NASA Tropospheric Emission Spectrometer. Quantitative analysis is the subject of ongoing work. These data are being used to confront a heirarchy of atmospheric chemistry mechanisms including the Master Chemical Mechanism and its reduced versions, embodying current knowledge, with the objective of understanding the level of detail sufficient to describe chemistry in the pyrogenic plumes and being able to implement that detail into a larger-scale chemistry transport model. Ongoing work shows that reduced versions of the MCM can largely reproduce the observed oxidant variability in the aircraft observations.

The level of coordination necessary to integrate a wide range of observations and models across a range of temporal and spatial scales, while often non-trivial, provides invaluable validation of the satellite data and confidence in our scaling up of aircraft measurements using models and global space-borne data. The remaining studies will largely focus on improving the integration of data and models. In the short term, we want to understand how these data together can improve the quantitative understanding of chemistry within the pyrogenic plumes and how we can transfer that information to improve global and regional models of atmospheric chemistry. These will partly be achieved by using a data assimilation methodology (e.g. Parrington et al., 2012) that can effectively extrapolate the detailed information collected during BORTAS-B to larger spatial domains. In the longer term, putting BORTAS-B into context with all similar previous studies using, for example, a consistent modelling framework will result in additional insights into the underlying chemistry associated with the pyrogenic environment. 
Acknowledgements. Airborne data were obtained using the BAe-146-301 Atmospheric Research Aircraft (ARA) operated by Directflight Ltd (DFL) and managed by the Facility for Airborne Atmospheric Measurements (FAAM), which is a joint entity of the Natural Environment Research Council (NERC) and the UK Meteorological Office. The BORTAS science team acknowledges the great efforts provided by the staff of FAAM, DFL, Avalon Aero Ltd and Captains Alan Foster and Charlie Whittaker and First Officer Ian Ramsay-Rae. We thank Environment Canada (EC) for meteorological forecasting support; R. Hoff (U. Maryland), and N. O'Neill (U. de Sherbrooke) for LiDAR and AOD measurements; G. Forbes, J. Davies, I. Beres, R. Mittermeier (EC), M. Osman (U. Western Ontario), A. Yamamoto (U. McGill), and L.-P. Beaudoin (Canadian Space Agency, CSA) for special ozonesonde launches; M. Bourqui (U. McGill) and H. He (EC) for trajectory forecasts; and most especially the many observers who obtained the ozonesonde measurements at the BORTAS sites. We also acknowledge Stephen Mobbs, who agreed to release additional NCAS flight hours during BORTAS. This research was supported by the Natural Environment Research Council under grant number NE/F017391/1. P. I. Palmer also acknowledges support from the Leverhulme Trust and the Nuffield Foundation. D. Moore and J. J. Remedios acknowledge funding from the NERC National Centre for Earth Observation. Funding for the ozonesondes was provided by Environment Canada and the Green Horse Society (for Sable Island). The measurements at the Dalhousie Ground Station were supported by the Natural Sciences and Engineering Research Council of Canada. The Atmospheric Chemistry Experiment (ACE), also known as SCISAT, is a Canadian-led mission mainly supported by the Canadian Space Agency and the Natural Sciences and Engineering Research Council (NSERC) of Canada. Funding for the TAO measurements was provided by NSERC, CSA, and EC.

Edited by: R. MacKenzie

\section{References}

Alvarado, M. J., Logan, J. A., Mao, J., Apel, E., Riemer, D., Blake, D., Cohen, R. C., Min, K.-E., Perring, A. E., Browne, E. C., Wooldridge, P. J., Diskin, G. S., Sachse, G. W., Fuelberg, H., Sessions, W. R., Harrigan, D. L., Huey, G., Liao, J., Case-Hanks, A., Jimenez, J. L., Cubison, M. J., Vay, S. A., Weinheimer, A. J., Knapp, D. J., Montzka, D. D., Flocke, F. M., Pollack, I. B., Wennberg, P. O., Kurten, A., Crounse, J., Clair, J. M. St., Wisthaler, A., Mikoviny, T., Yantosca, R. M., Carouge, C. C., and Le Sager, P.: Nitrogen oxides and PAN in plumes from boreal fires during ARCTAS-B and their impact on ozone: an integrated analysis of aircraft and satellite observations, Atmos. Chem. Phys., 10, 9739-9760, doi:10.5194/acp-10-9739-2010, 2010.

Andreae, M. O. and Merlet, P.: Emission of trace gases and aerosols from biomass burning, Global Biogeochem. Cy., 15, 955-966, doi:10.1029/2000GB001382, 2001.

Atkinson, R. and Arey, J.: Atmospheric degradation of volatile organic compounds, Chem. Rev., 103, 4605-4638, 2003.

Beer, R., Glavich, T. A., and Rider, D. M.: Tropospheric emission spectrometer for the Earth Observing System's Aura satellite, Appl. Optics, 40, 2356-2367, 2001.

Bernath, P. F., McElroy, C. T., Abrams, M. C., Boone, C. D., Butler, M., Camy-Peyret, C., Carleer, M., Clerbaux, C., Coheur, P. F.,
Colin, R., DeCola, P., DeMaziere, M., Drummond, J. R., Dufour, D., Evans, W. F. J., Fast, H., Fussen, D., Gilbert, K., Jennings, D. E., Llewellyn, E. J., Lowe, R. P., Mahieu, E., McConnell, J. C., McHugh, M., McLeod, S. D., Michaud, R., Midwinter, C., Nassar, R., Nichitiu, F., Nowlan, C., Rinsland, C. P., Rochon, Y. J., Rowlands, N., Semeniuk, K., Simon, P., Skelton, R., Sloan, J. J., Soucy, M. A., Strong, K., Tremblay, P., Turnbull, D., Walker, K. A., Walkty, I., Wardle, D. A., Wehrle, V., Zander, R., and Zou, J.: Atmospheric Chemistry Experiment (ACE): mission overview, Geophys. Res. Lett., 32, L15S01, doi:10.1029/2005GL022386, 2005.

Bitar, L., Duck, T. J., Kristiansen, N. I., Stohl, A., and Beaichamp, S.: Lidar observations of Kasatochi volcano aerosols in the troposphere and stratosphere, J. Geophys. Res., 115, D00L13, doi:10.1029/2009JD013650, 2010.

Bourqui, M. S., Yamamoto, A., Tarasick, D., Moran, M. D., Beaudoin, L.-P., Beres, I., Davies, J., Elford, A., Hocking, W., Osman, M., and Wilkinson, R.: A new global real-time Lagrangian diagnostic system for stratosphere-troposphere exchange: evaluation during a balloon sonde campaign in eastern Canada, Atmos. Chem. Phys., 12, 2661-2679, doi:10.5194/acp-12-26612012, 2012.

Christian, T. J., Kleiss, B., Yokelson, R. J., Holzinger, R., Crutzen, P. J., Hao, W. M., Shirai, T., and Blake, D. R.: Comprehensive laboratory measurements of biomass-burning emissions: 2. First intercomparison of open-path FTIR, PTRMS, and GC- MS/FID/ECD, J. Geophys. Res., 108, 4719, doi:10.1029/2003JD003704, 2004.

Clerbaux, C., Boynard, A., Clarisse, L., George, M., Hadji-Lazaro, J., Herbin, H., Hurtmans, D., Pommier, M., Razavi, A., Turquety, S., Wespes, C., and Coheur, P.-F.: Monitoring of atmospheric composition using the thermal infrared IASI/MetOp sounder, Atmos. Chem. Phys., 9, 6041-6054, doi:10.5194/acp-9-6041-2009, 2009.

Dacre, H. F., Grant, A. L. M., and Johnson, B. T.: Aircraft observations and model simulations of concentration and particle size distribution in the Eyjafjallajökull volcanic ash cloud, Atmos. Chem. Phys., 13, 1277-1291, doi:10.5194/acp-13-12772013, 2013.

Dari-Salisburgo, C., Carlo, P. D., Giammaria, F., Kajii, Y., and D'Altorio, A.: Laser induced fluorescence instrument for $\mathrm{NO}_{2}$ measurements: Observations at a central Italy background site, Atmos. Environ., 43, 970-977, 2008.

Di Carlo, P., Aruffo, E., Busilacchio, M., Giammaria, F., DariSalisburgo, C., Biancofiore, F., Visconti, G., Lee, J., Moller, S., Reeves, C. E., Bauguitte, S., Forster, G., Jones, R. L., and Ouyang, B.: Aircraft based four-channel thermal dissociation laser induced fluorescence instrument for simultaneous measurements of $\mathrm{NO}_{2}$, total peroxy nitrate, total alkyl nitrate, and $\mathrm{HNO}_{3}$, Atmos. Meas. Tech., 6, 971-980, doi:10.5194/amt-6-971-2013, 2013.

Draxler, R. R.: HYSPLIT4 user's guide, Tech. Rep. NOAA Tech. Memo. ERL ARL-230, NOAA Air Resources Laboratory, Silver Spring, MD, 1999.

Drysdale, D.: An Introduction to Fire Dynamics, John Wiley \& Sons, NOAA, 46 pp., 2008.

Fischer, H., Birk, M., Blom, C., Carli, B., Carlotti, M., von Clarmann, T., Delbouille, L., Dudhia, A., Ehhalt, D., Endemann, M., Flaud, J. M., Gessner, R., Kleinert, A., Koopman, R., Langen, J., 
López-Puertas, M., Mosner, P., Nett, H., Oelhaf, H., Perron, G., Remedios, J., Ridolfi, M., Stiller, G., and Zander, R.: MIPAS: an instrument for atmospheric and climate research, Atmos. Chem. Phys., 8, 2151-2188, doi:10.5194/acp-8-2151-2008, 2008.

Franklin, J. E., Griffin, D., Pierce, J. R., Drummond, J. R., Waugh, D., Palmer, P. I., Chisholm, L., Duck, T. J., Lesins, G., Walker, K. A., Hopper, J. T., Curry, K. R., Sakamoto, K. M., and O'Neill, $\mathrm{N}$.: Remote sensing of trace gases and aerosols in biomass burning plumes over eastern Canada during the BORTAS field campaign, in preparation, 2013.

Fu, D., Walker, K. A., Sung, K., Boone, C. D., Soucy, M.-A., and Bernath, P. F.: The portable atmospheric research interferometric spectrometer for the infrared, PARIS-IR, J. Quant. Spectrosc. Ra., 103, 362-370, 2007.

George, M., Clerbaux, C., Hurtmans, D., Turquety, S., Coheur, P.F., Pommier, M., Hadji-Lazaro, J., Edwards, D. P., Worden, H., Luo, M., Rinsland, C., and McMillan, W.: Carbon monoxide distributions from the IASI/METOP mission: evaluation with other space-borne remote sensors, Atmos. Chem. Phys., 9, 8317-8330, doi:10.5194/acp-9-8317-2009, 2009.

Gerbig, C., Schmitgen, S., Kley, D., Volz-Thoms, A., Dewey, K., and Haaks, D.: An improved fast-response vacuum-UV resonance fluorescence CO instrument, J. Geophys. Res., 104, 16991704, 1999.

Gibson, M. D., Heal, M. R., Bachse, D. H., Hursthouse, A. S., Beverland, I. J., Craig, S. E., Clak, C. F., Jackson, M. H., Guernsey, J. R., and Jones, C.: Using Mass Reconstruction along a FourSite Transect as a method to interpret PM10 in West-Central Scotland, J. Air Waste Manage., 59, 1429-1436, 2009.

Gibson, M. D., Pierce, J. R., Waugh, D., Kuchta, J. S., Chisholm, L., Duck, T. J., Hopper, J. T., Beauchamp, S., King, G. H., Franklin, J. E., Leaitch, W. R., Wheeler, A. J., Li, Z., Gagnon, G. A., and Palmer, P. I.: Identifying the sources driving observed $\mathrm{PM}_{2.5}$ variability over Halifax, Nova Scotia, during BORTAS-B, Atmos. Chem. Phys. Discuss., 13, 4491-4533, doi:10.5194/acpd13-4491-2013, 2013.

Gibson, M. D., Kuchta, J., Chisholm, L., Duck, T., Hopper, J., Beauchamp, S., Waugh, D., King, G., Pierce, J., Li, Z., Leaitch, R., Ward, T. J., and Palmer, P. I.: Receptor modelling of boreal wildfire associated $\mathrm{PM}_{2.5}$ in Halifax, Nova Scotia, Canada, Geophysical Research Abstracts, 15, EGU2013-1604, 2013 EGU General Assembly, Vienna, 7-12 April 2013.

Griffin, D., Walker, K. A., Franklin, J. E., Parrington, M., Whaley, C., Hopper, J., Drummond, J. R., Palmer, P. I., Strong, K., Duck, T. J., Abboud, I., Bernath, P. F., Clerbaux, C., Coheur, P.F., Curry, K. R., Dan, L., Hyer, E., Kliever, J., Lesins, G., Maurice, M., Saha, A., Tereszchuk, K., and Weaver, D.: Investigation of $\mathrm{CO}, \mathrm{C}_{2} \mathrm{H}_{6}$ and aerosols in a boreal fire plume over eastern Canada during BORTAS 2011 using ground- and satellitebased observations, and model simulations, Atmos. Chem. Phys. Discuss., 13, 11071-11109, doi:10.5194/acpd-13-11071-2013, 2013.

Hays, M. D., Geron, C. D., Linna, K. J., Smith, N. D., and Schauer, J. J.: Speciation of gas-phase and fine particle emissions from burning of foliar fuels, Environ. Sci. Technol., 36, 2281-2295, doi:10.1021/es0111683, 2002.

Hennigan, C. J., Sullivan, A. P., Collett, J. L., and Robinson, A. L.: Levoglucosan stability in biomass burning particles exposed to hydroxyl radicals, Geophys. Res. Lett., 37, L09806,
doi:10.1029/2010GL043088, 2010.

Hogg, A., Johnson, C., Sparks, S., Huppert, H., Woodhouse, M., and Phillips, J.: Models of ash-laden intrusions in a stratified atmosphere, Geophysical Research Abstracts, 15, EGU2013-9726, 2013 EGU General Assembly, Vienna, 7-12 April 2013.

Holben, B. N., Eck, T. F., Slutsker, I., Tanre, D., Buis, J. P., Setzer, A., Vermote, E., Reagan, J. A., Kaufman, Y., Nakajima, T., Lavenu, F., Jankowiak, I., and Smirnov, S.: AERONET - A federated instrument network and data archive for aerosol characterization, Remote. Sens. Environ., 66, 1-16, 1998.

Honrath, R. E., Owen, R. C., Martin, M. V., Reid, J. S., Lapina, K., Fialho, P., Dziobak, M. P., Kleissl, J., and Westphal, D. L.: Regional and hemispheric impacts of anthropogenic and biomass burning emissions on summertime $\mathrm{CO}$ and $\mathrm{O}_{3}$ in the North Atlantic lower free troposphere, J. Geophys. Res., 109, D24310, doi:10.1029/2004JD005147, 2004.

Honrath, R. E., Helmig, D., Owen, R. C., Parrish, D. D., and Tanner, D. M.: Nonmethane hydrocarbons at Pico Mountain, Azores: 2. Event-specific analyses of the impacts of mixing and photochemistry on hydrocarbon ratios, J. Geophys. Res., 113, D20S92, doi:10.1029/2008JD009832, 2008.

Hopkins, J. R., Read, K. A., and Lewis, A. C.: Two column method for long-term monitoring of non-methane hydrocarbons (NMHCs) and oxygenated volatile organic compounds, J. Environ. Monitor., 5, 8-13, 2003.

Illingworth, S. M., Remedios, J. J., Boesch, H., Moore, D. P., Sembhi, H., Dudhia, A., and Walker, J. C.: ULIRS, an optimal estimation retrieval scheme for carbon monoxide using IASI spectral radiances: sensitivity analysis, error budget and simulations, Atmos. Meas. Tech., 4, 269-288, doi:10.5194/amt-4-269-2011, 2011.

Jacob, D. J., Crawford, J. H., Maring, H., Clarke, A. D., Dibb, J. E., Emmons, L. K., Ferrare, R. A., Hostetler, C. A., Russell, P. B., Singh, H. B., Thompson, A. M., Shaw, G. E., McCauley, E., Pederson, J. R., and Fisher, J. A.: The Arctic Research of the Composition of the Troposphere from Aircraft and Satellites (ARCTAS) mission: design, execution, and first results, Atmos. Chem. Phys., 10, 5191-5212, doi:10.5194/acp-10-5191-2010, 2010.

Jaffe, D. A. and Wigder, N. L.: Ozone production from wildfires: a critical review, Atmos. Environ., 51, 1-10, 2012.

Jayne, J. T., Heard, D. C., Zhang, X. F., Davidovits, P., Smith, K. A., Kolb, C. E., and Worsnop, D. R.: Development of an aerosol mass spectrometer for size and composition analysis of submicron particles, Aerosol Sci. Tech., 33, 49-70, 2000.

Jenkin, M., Watson, L., Utembe, S., and Shallcross, D.: A Common Representative Intermediates (CRI) mechanism for VOC degradation. Part 1: Gas phase mechanism development, Atmos. Environ., 42, 7185-7195, doi:10.1016/j.atmosenv.2008.07.028, 2008.

Jeong, C.-H., Evans, G. J., Dann, T., Graham, M., Herod, D., Dabek-Ziotorzynska, E., Mathieu, D., Ding, L., and Wang, D.: Influence of biomass burning on wintertime fine particulate matter: source contribution at a valley site in rural British Columbia, Atmos. Environ., 42, 3684-3699, 2008.

Junkermann, W., Platt, U., and Volz-Thomas, A.: A photoelectric detector for the measurement of photolysis frequencies of ozone and other atmospheric molecules, J. Atmos. Chem., 8, 203-227, 1989.

Keil, C. and Craig, G. C.: A displacement and amplitude score employing an optical flow technique, Weather Forecast., 24, 1297 
1308, doi:10.1175/2009WAF2222247.1, 2009.

Kulawik, S. S., Bowman, K. W., Luo, M., Rodgers, C. D., and Jourdain, L.: Impact of nonlinearity on changing the a priori of trace gas profile estimates from the Tropospheric Emission Spectrometer (TES), Atmos. Chem. Phys., 8, 3081-3092, doi:10.5194/acp-8-3081-2008, 2008.

Larson, T., Gould, T., Simpson, C., Liu, L. J., Claiborn, C., and Lewtas, J.: Source apportionment of indoor, outdoor, and personal PM2.5 in Seattle, Washington, using positive matrix factorization, J. Air Waste Manage., 54, 1175-1187, 2004.

Lee, J. D., Moller, D. J., Read, K. A., Lewis, A. C., Mendes, L., and Carpenter, L. J.: Year-round measurements of nitrogen oxides and ozone in the tropical North Atlantic marine boundary laer, J. Geophys. Res., 114, D21302, doi:10.1029/2009JD011878, 2009.

Leiterer, U., Naebert, A., Naebert, T., and Alekseeva, G.: A new star photometer developed for spectral aerosol optical thickness measurements in Lindenberg, Contrib. Atmos. Phys., 68, 133$141,1995$.

Lenschow, D. H.: Probing the atmospheric boundary layer, chap. Aircraft measurements in the boundary layer, 39-55, Amer. Meteor. Soc., 1986.

Lewis, A. C., Evans, M. J., Methven, J., Watson, N., Lee, J. D., Hopkins, J. R., Purvis, R. M., Arnold, S. R., McQuaid, J. B., Whalley, L. K., Pilling, M. J., Heard, D. E., Monks, P. S., Parker, A. E., Reeves, C. E., Oram, D. E., Mills, G., Bandy, B. J., Stewart, D., Coe, H., Williams, P., and Crosier, J.: Chemical composition observed over the mid-Atlantic and the detection of pollution signatures far from source regions, J. Geophys. Res., 112, D10S39, doi:10.1029/2006JD007584, 2007.

Lewis, A. C., Evans, M. J., Hopkins, J. R., Punjabi, S., Read, K. A., Purvis, R. M., Andrews, S. J., Moller, S. J., Carpenter, L. J., Lee, J. D., Rickard, A. R., Palmer, P. I., and Parrington, M.: The influence of biomass burning on the global distribution of selected non-methane organic compounds, Atmos. Chem. Phys., 13, 851-867, doi:10.5194/acp-13-851-2013, 2013.

Marple, V. A., Rubow, K. L., and Behm, S. M.: A Microorifice Uniform Deposit Impactor (MOUDI): Description, calibration, and use, Aerosol Sci. Tech., 14, 434-446, doi:10.1080/02786829108959504, 1991.

Matthiesen, S., Palmer, P. I., and Parrington, M.: Development of a 3-dimensional quality forecast measure for plume forecasts, in preparation, 2013.

McConnell, C. L., Formenti, P., Highwood, E. J., and Harrison, M. A. J.: Using aircraft measurements to determine the refractive index of Saharan dust during the DODO Experiments, Atmos. Chem. Phys., 10, 3081-3098, doi:10.5194/acp-10-30812010, 2010.

Monks, P. S., Granier, C., Fuzzi, S., Stohl, A., Williams, M. L., Akimoto, H., Amann, M., Baklanov, A., Baltensperger, U., Bey, I., Blake, N., Blake, R. S., Carslaw, K., Cooper, O. R., Dentener, F., Fowler, D., Fragkou, E., Frost, G. J., Generoso, S., Ginoux, P., Grewe, V., Guenther, A., Hansson, H. C., Henne, S., Hjorth, J., Hofzumahaus, A., Huntrieser, H., Isaksen, I. S. A., Jenkin, M. E., Kaiser, J., Kanakidou, M., Klimont, Z., Kulmala, M., Laj, P., Lawrence, M. G., Lee, J. D., Liousse, C., Maione, M., McFiggans, G., Metzger, A., Mieville, A., Moussiopoulos, N., Orlando, J. J., O’Dowd, C. D., Palmer, P. I., Parrish, D. D., Petzold, A., Platt, U., Pöschl, U., Prevot, A. S. H., Reeves, C. E., Reimann, S., Rudich, Y., Sellegri, K., Steinbrecher, R., Simpson, D., ten
Brink, H., Theloke, J., van der Werf, G. R., Vautard, R., Vestreng, V., Vlachokostas, Ch., and von Glasow, R.: Atmospheric composition change global and regional air quality, Atmos. Environ., 43, 5268-5350, doi:10.1016/j.atmosenv.2009.08.021, 2009.

Moore, D. P. and Remedios, J. J.: Seasonality of Peroxyacetyl nitrate (PAN) in the upper troposphere and lower stratosphere using the MIPAS-E instrument, Atmos. Chem. Phys., 10, 6117-6128, doi:10.5194/acp-10-6117-2010, 2010.

Moore, D. P., Remedios, J. J., and Waterfall, A. M.: Global distributions of acetone in the upper troposphere from MIPAS spectra, Atmos. Chem. Phys., 12, 757-768, doi:10.5194/acp-12-7572012, 2012.

Mota, B. W., Pereira, J. M. C., Oom, D., Vasconcelos, M. J. P., and Schultz, M.: Screening the ESA ATSR-2 World Fire Atlas (1997-2002), Atmos. Chem. Phys., 6, 1409-1424, doi:10.5194/acp-6-1409-2006, 2006.

Mu, M., Randerson, J. T., van der Werf, G. R., Giglio, L., Kasibhatla, P., Morton, D., Collatz, G. J., DeFries, R. S., Hyer, E. J., Prins, E. M., Griffiths, D. W. T., Wunch, D., Toon, G. C., Sherlock, V., and Wennberg, P. O.: Daily and 3-hourly variability in global fire emissions and consequences for atmospheric model predictions of carbon monoxide, J. Geophys. Res., 116, D24303, doi:10.1029/2011JD016245, 2011.

Murphy, J. G., Oram, D. E., and Reeves, C. E.: Measurements of volatile organic compounds over West Africa, Atmos. Chem. Phys., 10, 5281-5294, doi:10.5194/acp-10-5281-2010, 2010.

Ng, N. L., Herndon, S. C., Trimborn, A., Canagaratna, M. R., Croteau, P., Onasch, T. B., Sueper, D., Worsnop, D. R., Zhang, Q., Sun, Y. L., and Jayne, J. T.: An Aerosol Chemical Speciation Monitor (ACSM) for routine monitoring of the composition and mass concentrations of ambient aerosol, Aerosol Sci. Tech., 45, 770-784, doi:10.1080/02786826.2011.560211, 2011.

Olivier, J. G. J. and Berdowski, J. J. M.: The Climate System, Chap. Global Emissions Sources and Sinks, A.A. Balkema Publishers/Swets \& Zeitlinger Publishers, Lisse, The Netherlands, ISBN 905809255 0, 33-78, 2001.

Olszyna, K. J., Bailey, E. M., Simonaitis, R., and Meagher, J. F.: $\mathrm{O}_{3}$ and $\mathrm{NO}_{\mathrm{y}}$ relationships at a rural site, J. Geophys. Res., 99, 14557-14563, 1994.

O'Shea, S. J., Bauguitte, S. J.-B., Gallagher, M. W., Lowry, D., and Percival, C. J.: Development of a cavity-enhanced absorption spectrometer for airborne measurements of $\mathrm{CH}_{4}$ and $\mathrm{CO}_{2}$, Atmos. Meas. Tech., 6, 1095-1109, doi:10.5194/amt-6-1095-2013, 2013.

Ott, L., Pawson, S., and Bacmeister, J.: An analysis of the impact of convective parameter sensitivity on simulated global atmospheric CO distributions, J. Geophys. Res., 116, D21310, doi:10.1029/2011JD016077, 2011.

Paatero, P. and Trapper, U.: Positive matrix factorization: a nonnegative factor model with optimal utilization of error estimates of data values, Environmetrics, 5, 111-126, 1994.

Parker, R. J., Remedios, J. J., Moore, D. P., and Kanawade, V. P.: Acetylene $\mathrm{C}_{2} \mathrm{H}_{2}$ retrievals from MIPAS data and regions of enhanced upper tropospheric concentrations in August 2003, Atmos. Chem. Phys., 11, 10243-10257, doi:10.5194/acp-1110243-2011, 2011.

Parrington, M., Palmer, P. I., Henze, D. K., Tarasick, D. W., Hyer, E. J., Owen, R. C., Helmig, D., Clerbaux, C., Bowman, K. W., Deeter, M. N., Barratt, E. M., Coheur, P.-F., Hurtmans, D., Jiang, 
Z., George, M., and Worden, J. R.: The influence of boreal biomass burning emissions on the distribution of tropospheric ozone over North America and the North Atlantic during 2010, Atmos. Chem. Phys., 12, 2077-2098, doi:10.5194/acp-12-20772012, 2012.

Parrington, M., Palmer, P. I., Lewis, A. C., Lee, J. D., Rickard, A. R., Di Carlo, P., Taylor, J. W., Hopkins, J. R., Punjabi, S., Oram, D. E., Forster, G., Aruffo, E., Moller, S. J., Bauguitte, S. J.-B., Allan, J. D., Coe, H., and Leigh, R. J.: Ozone photochemistry in boreal biomass burning plumes, Atmos. Chem. Phys. Discuss., 13, 1795-1853, doi:10.5194/acpd-13-1795-2013, 2013.

Parrish, D. D., Stohl, A., Forster, C., Atlas, E. L., Blake, D. R., Goldan, P. D., Kuster, W. C., and de Gouw, J. A.: Effects of mixing on evolution of hydrocarbon ratios in the troposphere, J. Geophys. Res., 112, D10S34, doi:10.1029/2006JD007583, 2007.

Petersen, G. N. and Renfrew, I. A.: Aircraft-based observations of air-sea fluxes over Denmark Strait and the Irminger Sea during high wind speed conditions, Q. J. Roy. Meteor. Soc., 135, 20302045, 2009.

Purvis, R. M., Lews, A. C., Hopkins, J. R., Andrews, S., and Minaean, J.: Functionalized aromatic compounds within middle troposphere boreal biomass burning plumes, in preparation, 2013.

Real, E., Law, K. S., Weinzierl, B., Fiebig, M., Petzold, A., Wild, O., Methven, J., Arnold, S., Stohl, A., Huntrieser, H., Roiger, A., Schlager, H., Stewart, D., Avery, M., Sachse, G., Browell, E., Ferrare, R., and Blake, D.: Processes influencing ozone levels in Alaskan forest fire plumes during long-range transport over the North Atlantic, J. Geophys. Res., 112, D10S41, doi:10.1029/2006JD007576, 2007.

Reid, J. S., Hyer, E. J., Prins, E. M., Westphal, D. L., Zhang, J., Wang, J., Christopher, S. A., Curtis, C. A., Schmidt, C. C., Eleuterio, D. P., Richardson, K. A., and Hoffman, J. P.: Global monitoring and forecasting of biomass burning smoke: Description of and lessons from the Fire Locating and Modeling of Burning Emissions (FLAMBE) program, IEEE J. Sel. Top. Appl., 2, 144-162, 2009.

Reidmiller, D. R., Jaffe, D. A., Fischer, E. V., and Finley, B.: Nitrogen oxides in the boundary layer and free troposphere at the Mt. Bachelor Observatory, Atmos. Chem. Phys., 10, 6043-6062, doi:10.5194/acp-10-6043-2010, 2010.

Rickard, A. R., Salisbury, G., Monks, P. S., Lewis, A. C., Baugitte, S., Bandy, B. J., Clemitshaw, K. C., and Penkett, S. A.: Comparison of measured ozone production efficiencies in the marine boundary layer at two European coastal sites under different pollution regimes, J. Atmos. Chem., 43, 107-134, 2002.

Rienecker, M. M., Suarez, M. J., Todling, R., Bacmeister, J., Takacs, L., Liu, H.-C., Gu, W., Sienkiewicz, M., Koster, R. D., Gelaro, I., and Nielsen, J. E.: The GEOS-5 Data Assimilation System - Documentation of Versions 5.0.1, 5.1.0, and 5.2.0, Tech. rep., NASA Goddard, 2008.

Rodgers, C. D. and Connor, B. J.: Intercomparison of remote sounding instruments, J. Geophys. Res., 108, 4116, doi:10.1029/2002JD002299, 2003.

Ryerson, T. B., Trainer, M., Holloway, J. S., Parrish, D. D., Huey, L. G., Sueper, D. T., Frost, G. J., Donnelley, S. G., Schauffer, S., Atlas, E. L., Kuster, W. C., Goldan, P. D., Hübler, G., and Meagher, J. F.: Observations of ozone formation in power plant plumes and implications for ozone control strategies, Science, 292, 719-723, doi:10.1126/science.1058113, 2001.
Saunders, S. M., Jenkin, M. E., Derwent, R. G., and Pilling, M. J.: Protocol for the development of the Master Chemical Mechanism, MCM v3 (Part A): tropospheric degradation of nonaromatic volatile organic compounds, Atmos. Chem. Phys., 3, 161-180, doi:10.5194/acp-3-161-2003, 2003.

Simoneit, B. R. T., Schauer, J. J., Nolte, C. G., Oros, D. R., Elias, V. O., Fraser, M. P., Rogge, W. F., and Cass, G. R.: Levoglucosan, a tracer for cellulose in biomass burning and atmospheric particles, Atmos. Environ., 33, 173-182, 1999.

Simpson, I. J., Akagi, S. K., Barletta, B., Blake, N. J., Choi, Y., Diskin, G. S., Fried, A., Fuelberg, H. E., Meinardi, S., Rowland, F. S., Vay, S. A., Weinheimer, A. J., Wennberg, P. O., Wiebring, P., Wisthaler, A., Yang, M., Yokelson, R. J., and Blake, D. R.: Boreal forest fire emissions in fresh Canadian smoke plumes: $\mathrm{C} 1-\mathrm{C} 10$ volatile organic compounds (VOCs), $\mathrm{CO}_{2}, \mathrm{CO}, \mathrm{NO}_{2}$, NO, HCN and CH3CN, Atmos. Chem. Phys., 11, 6445-6463, doi:10.5194/acp-11-6445-2011, 2011.

Singh, H. B., Anderson, B. E., Brune, W. H., Cai, C., Cohen, R. C., Crawford, J. H., Cubison, M. J., Czech, E. P., Emmons, L., Fuelberg, H. E., Guey, G., Jacob, D. J., Jimenez, J. L., Kaduwela, A., Kondo, Y., Mao, J., Olson, J. R., Sachse, G. W., Vay, S. A., Weinheimer, A., Wennberg, P. O., Wisthaler, A., and ARCTAS Science Team: Pollution influences on atmospheric composition and chemistry at high northern latitudes: Boreal and California forest fire emissions, Atmos. Environ., 44, 4553-4564, 2010.

Song, X.-H., Polissar, A. V., and Hopke, P. K.: Sources of fine particle composition in the northeastern US, Atmos. Environ., 35, 5277-5286, 2001

Strawbridge, K. B.: Developing a portable, autonomous aerosol backscatter lidar for network or remote operations, Atmos. Meas. Tech., 6, 801-816, doi:10.5194/amt-6-801-2013, 2013.

Ström, J., Busen, R., Quante, M., Guillemet, B., Brown, P. R. A., and Heintzenberg, J.: Pre-EUCREX intercomparison of airborne humidity measuring instruments, J. Atmos. Tech., 11, 1392 1399, 1994.

Tereszchuk, K. A., González Abad, G., Clerbaux, C., Hurtmans, D., Coheur, P.-F., and Bernath, P. F.: ACE-FTS measurements of trace species in the characterization of biomass burning plumes, Atmos. Chem. Phys., 11, 12169-12179, doi:10.5194/acp-1112169-2011, 2011.

Tereszchuk, K. A., González Abad, G., Clerbaux, C., Hadji-Lazaro, J., Hurtmans, D., Coheur, P.-F., and Bernath, P. F.: ACE-FTS observations of pyrogenic trace species in boreal biomass burning plumes during BORTAS, Atmos. Chem. Phys. Discuss., 12, 31629-31661, doi:10.5194/acpd-12-31629-2012, 2012.

Tereszchuk, K. A., Moore, D. P., Harrison, J. J., Boone, C. D., Park, M., Remedios, J. J., Randel, W. J., and Bernath, P. F.: Observations of peroxyacetyl nitrate (PAN) in the upper troposphere by the Atmospheric Chemistry Experiment Fourier Transform Spectrometer (ACE-FTS), Atmos. Chem. Phys. Discuss., 13, 15751607, doi:10.5194/acpd-13-1575-2013, 2013.

Verma, S., Worden, J., Pierce, B., Jones, D. B. A., Al-Saadi, J., Boersma, F., Bowman, K., Eldering, A., Fisher, B., Jourdain, L., Kulawik, S., and Worden, H.: Ozone production in boreal fire smoke plumes using observation from the Tropospheric Emission Spectrometer and the Ozone Monitoring Instrument, J. Geophys. Res., 114, D02303, doi:10.1029/2008JD010108, 2009.

Volz-Thomas, A., Lerner, A., Pätz, H.-W., Schultz, M., McKenna, D. S., Schmitt, R., Madronich, S., and Röth, E. P.: Airborne mea- 
surements of the photolysis frequency of $\mathrm{NO}_{2}$, J. Geophys. Res., 101, 18613-18627, 1996.

Ward, T., Trost, B., Conner, J., Flanagan, J., and Jayanty, R. K. M.: Source apportionment of PM2.5 in a subarctic airshed, Fairbanks, Alaska, Aerosol Air Qual. Res., 12, 536-543, 2012.

Watson, L., Shallcross, D., Utembe, S., and Jenkin, M.: A Common Representative Intermediates (CRI) mechanism for VOC degradation. Part 2: Gas phase mechanism reduction, Atmos. Environ., 42, 7196-7204, doi:10.1016/j.atmosenv.2008.07.034, 2008.

Whalley, L. K., Lewis, A. C., McQuaid, J. B., Purvis, R. M., Lee, J. D., Stemmler, K., Zellweger, C., and Ridgeon, P.: Nonmethane hydrocarbons and PAN at the Jungfraujoch High Altitude Station: a test of chromatography instruments designed for use on research aircraft., J. Environ. Monitor., 6, 234-241, 2004.
Wiacek, A., Taylor, J. R., Strong, K., Saari, R., Kerzenmacher, T. E., Jones, N. B., and Griffith, D. W. T.: Ground-based solar absorption FTIR spectroscopy: characterization of retrievals and first results from a novel optical design instrument at a new NDACC complementary station, J. Atmos. Ocean. Tech., 24, 432, doi:10.1175/JTECH1962.1, 2007.

Wilson, K. L. and Birks, J. W.: Mechanism and elimination of a water vapor interferences in the measurement of ozone by UV absorbance, Environ. Sci. Technol., 40, 6361-6367, 2006.

Yokelson, R. J., Christian, T. J., Karl, T. G., and Guenther, A.: The tropical forest and fire emissions experiment: laboratory fire measurements and synthesis of campaign data, Atmos. Chem. Phys., 8, 3509-3527, doi:10.5194/acp-8-3509-2008, 2008.

Young, J., Rickard, A. R., Jenkin, M. E., Parrington, D. S. M., Palmer, P. I., and et al.: Net Ozone Production During the Chemical Evolution of Biomass Burning Plumes: Evaluation of a Hierarchy of Chemical Mechanisms, in preparation, 2013. 